\title{
Hydrothermal $\mathrm{SiO}_{2}$ Nanopowders: Obtaining Them and Their Characteristics
}

\author{
Vadim Potapov ${ }^{1}$, Roman Fediuk ${ }^{2, *}$ and Denis Gorev ${ }^{1}$ (D) \\ 1 Research Geotechnological Center, Far Eastern Branch of Russian Academy of Sciences, 30, \\ Severo-Vostochny Highway, 683002 Petropavlovsk-Kamchatsky, Russia; vadim_p@inbox.ru (V.P.); \\ denis.goreff2015@yandex.ru (D.G.) \\ 2 School of Engineering, Far Eastern Federal University, 8, Sukhanova Str., 690950 Vladivostok, Russia \\ * Correspondence: roman44@yandex.ru; +79502817945
}

Received: 21 February 2020; Accepted: 25 March 2020; Published: 27 March 2020

check for updates

\begin{abstract}
The technological mode of obtaining amorphous $\mathrm{SiO}_{2}$ nanopowders based on hydrothermal solutions is proposed in this study. Polycondensation of orthosilicic acid as well as ultrafiltration membrane separation, and cryochemical vacuum sublimation were used. The characteristics of nanopowders were determined by tunneling electron microscopy, low-temperature nitrogen adsorption, X-ray diffraction, and small-angle X-ray scattering. The scheme allows to adjust density, particle diameters of nanopowders, specific surface area, as well as diameters, area and volume of the pore. Thus, the structure of nanopowders is regulated-the volume fraction of the packing of spherical particles in aggregates and agglomerates, the size of agglomerates, and the number of particles in agglomerates. The pour densities of the nanopowders depend on the $\mathrm{SiO}_{2}$ content in sols, which were 0.02 to $0.3 \mathrm{~g} / \mathrm{cm}^{3}$. Nanoparticles specific surface area was brought to $500 \mathrm{~m}^{2} / \mathrm{g}$ by low temperature polycondensation. Nanoparticle aggregates specific pore volume $\left(0.2-0.3 \mathrm{~g} / \mathrm{cm}^{3}\right)$ weakly depend on powders density. The volume fraction of the packing of $\mathrm{SiO}_{2}$ nanoparticles in aggregates was 0.6-0.7. Solid samples of compacted nanopowders had a compressive strength of up to $337 \mathrm{MPa}$. Possible applications of hydrothermal $\mathrm{SiO}_{2}$ nanopowders are considered.
\end{abstract}

Keywords: hydrothermal solution; polycondensation of orthosilicic acid; ultrafiltration membrane separation; cryochemical vacuum sublimation; diameter of $\mathrm{SiO}_{2}$ nanoparticles; nanopowder structure

\section{Introduction}

To date, a wide range of methods for producing various types of powders of amorphous dioxide silicon are known. At the same time, the need for $\mathrm{SiO}_{2}$ nanopowders-particles which have a high specific surface area up to $1000 \mathrm{~m}^{2} / \mathrm{g}$ and significant chemical activity-is increasing. Cheap sources of such materials and low-cost technologies for their production are needed.

Traditional applications of $\mathrm{SiO}_{2}$ nanopowders are known for the production of ceramics, glass, catalyst supports, sorbents, rubber fillers, polymeric materials, paper, abrasive materials, and medical preparations [1]. In the large-scale production of pyrogenic $\mathrm{SiO}_{2}$ nanopowders, the flame hydrolysis of $\mathrm{SiCl}_{4}$ in an atmosphere $\left(\mathrm{H}_{2}-\mathrm{O}_{2}\right)$ is used [1]. The flame temperature, flow rate and volumetric proportions of $\mathrm{SiCl}_{4}, \mathrm{H}_{2}, \mathrm{O}_{2}$ gases, control the size and specific surface area of the nanoparticles. Another major production is the production of silica fume by condensation of gases in ferroalloy furnaces (condensed silica fume).

Another group of methods is based on the preparation of $\mathrm{SiO}_{2}$ particles from the liquid phase using a sol-gel transition. This group includes the preparation of $\mathrm{SiO}_{2}$ silicogels using a sol-gel transition followed by subcritical or supercritical gel drying [2,3]. In this case, the hydrolysis and polycondensation of molecules and the preparation of sols of colloidal particles of $\mathrm{SiO}_{2}$ are used 
at the first stage of the process. The precursors of $\mathrm{SiO}_{2}$ sols are metal alkoxides and chlorides, tetraethoxysilane and alkali metal silicates $(\mathrm{Na}, \mathrm{K}, \mathrm{Li})$. At the gel stage, acid treatment with formamide is used to control the porous structure [4,5], and one of the most important parameters is the $\mathrm{pH}$ of the medium. The sol-gel method has produced a large number of mesoporous materials with a wide range of applications [6-19].

To obtain mesoporous materials, different variants of the Stober synthesis are used with the use of template additives of surfactants, water-soluble polymers, and previously obtained dense particles of sols [20]. Various forms of surfactant micellar solutions are used to synthesize mesoporous $\mathrm{SiO}_{2}$ particles [21-28]. $\mathrm{SiO}_{2}$ mesospheres are also synthesized with preliminary coagulation of the sol with electrolytes and subsequent polymer addition to separate the aggregates and prevent them from sticking together during drying [29]. There are methods for the synthesis of mixed oxides, hollow spheres, and objects of the core-mesoporous shell type [30,31]. $\mathrm{SiO}_{2}$ is one of the most common components for producing nanopowders, optical elements, medical preparations, thin films, fibers, nanotubes, nanowires, additives to hard films to increase tensile strength, hardness of hybrid coatings, and porous composite ceramics, $\mathrm{SiO}_{2}-\mathrm{Me}_{\mathrm{x}} \mathrm{O}_{\mathrm{y}}$ nanocomposites [32-45]. The possibility of obtaining colloidal $\mathrm{SiO}_{2}$ based on cheap waste of glass powder was shown in [46]. The production of $\mathrm{SiO}_{2}$ powders from rice husk has been developed as well [47].

Hydrothermal solutions are a new raw material source for the production of $\mathrm{SiO}_{2}$ nanopowders. For its development, it is necessary to develop a technology for producing $\mathrm{SiO}_{2}$ nanopowders taking into account the parameters of the hydrothermal medium: temperature, $\mathrm{pH}$, mineralization, ionic strength, polycondensation kinetics of orthosilicic acid, sizes and concentration of $\mathrm{SiO}_{2}$ particles, and stability of $\mathrm{SiO}_{2}$ nanoparticles in an aqueous medium.

The objectives of this article were:

- Create a technological route for the production of $\mathrm{SiO}_{2}$ nanopowders based on a hydrothermal solution with specific surface area up to $500 \mathrm{~m}^{2} / \mathrm{g}$ using the methods of ultrafiltration membrane separation and cryochemical vacuum sublimation.

- Create regulation parameters of the structure of the nanopowders: the diameters of $\mathrm{SiO}_{2}$ nanoparticles, specific surface area of nanopowders, diameters and specific pore volume, pour density, volume fraction of spherical particles in aggregates and agglomerates, sizes of agglomerates and number of particles in agglomerates.

- Assessment of possible applications of the obtained nanopowders.

\section{Materials and Methods}

\subsection{Methods for Producing Nanopowders}

Silica is formed in a hydrothermal solution from molecules of orthosilicic acid (OSA), which comes from the chemical interaction of water of a hydrothermal solution with aluminosilicate minerals of rocks (orthoclase, microcline $\mathrm{K}\left(\mathrm{AlSi}_{3} \mathrm{O}_{8}\right)$, albite $\mathrm{Na}\left(\mathrm{AlSi}_{3} \mathrm{O}_{8}\right)$, anorthite $\mathrm{Ca}\left(\mathrm{Al}_{2} \mathrm{Si}_{2} \mathrm{O}_{8}\right.$, etc.) in the bowels of hydrothermal deposits at high pressures (10-25 MPa and above) and temperatures $\left(250-300{ }^{\circ} \mathrm{C}\right.$ and above). As the solution rises to the surface through the productive wells of geothermal power plants (GeoPP), temperature and pressure decrease, and the solution becomes supersaturated with respect to the solubility of $C_{e}$ amorphous silica. In the solution, polycondensation and nucleation of OSA molecules occur, leading to the formation of spherical silica nanoparticles with a diameter of 5 to $100 \mathrm{~nm}$. In addition to silica, other components are in solution, the concentrations of which are given in Table 1. Silica is in solution in two states: solid $\left(\mathrm{SiO}_{2}\right.$ particles) and dissolved (OSA molecules). 
Table 1. The concentration of the main components of the initial hydrothermal solution.

\begin{tabular}{cccccccccccccc}
\hline Component & $\mathrm{Na}^{+}$ & $\mathrm{K}^{+}$ & $\mathbf{L i}^{+}$ & $\mathrm{Ca}^{2+}$ & $\mathbf{M g}^{2+}$ & $\mathrm{Fe}^{2+, 3+}$ & $\mathbf{A l}^{3+}$ & $\mathrm{Cl}^{-}$ & $\mathbf{S O}_{4}{ }^{2}$ & $\mathbf{H C O}_{3}^{-}$ & $\mathbf{C O}_{3}{ }^{2-}$ & $\mathbf{H}_{3} \mathbf{B O}_{3}$ & $\mathrm{SiO}_{2}$ total \\
\hline $\begin{array}{c}\text { Concentration, } \\
\mathrm{mg} / \mathrm{dm}^{3}\end{array}$ & 282 & 48.1 & 1.5 & 2.8 & 4.7 & $<0.1$ & $<0.1$ & 251.8 & 220.9 & 45.2 & 61.8 & 91.8 & 780 \\
\hline
\end{tabular}

Ionic strength of the solution $I_{S}=14.218 \mathrm{mmol} / \mathrm{kg}$, electrical conductivity $\sigma_{e l}=1.1-1.3 \mathrm{mS} / \mathrm{cm}, \mathrm{pH}=9.2$.

At the first stage of the process, OSA polycondensation and the growth of $\mathrm{SiO}_{2}$ nanoparticles were carried out at a certain temperature and $\mathrm{pH}$ of the hydrothermal solution. The final particle sizes of silica depend primarily on the temperature and $\mathrm{pH}$ at which the polycondensation of OSA molecules takes place. An increase in the polycondensation temperature and a decrease in $\mathrm{pH}$ slow down the reaction and increase the final particle size.

At the polycondensation stage, the temperature ranged from 20 to $90{ }^{\circ} \mathrm{C}$ (by preliminary cooling in heat exchangers), $\mathrm{pH}=8.0-9.3$. The range of silica concentrations in the initial solution is $\mathrm{Ct}=400-800 \mathrm{mg} / \mathrm{kg}$ ( $\mathrm{t}$ indicates the total silica content equal to the sum of the concentrations of the colloidal phase and dissolved Cs). The nucleation rate of silicic acid in an aqueous solution $(\mathrm{nucl} /(\mathrm{kg} \cdot \mathrm{s}))$ is described by Equation (1) [48-50]:

$$
I_{N}=Q_{L P} \times Z \times R_{M D} \times A_{c r} \times N_{A} \times M_{S i}^{-1} \times e^{-\Delta F_{c r} / k_{B} \times T},
$$

where $Q_{\mathrm{LP}}=3.34 \times 10^{25} \mathrm{~kg}^{-1}$-the Lohse-Pound factor; $k_{B}$-the Boltzmann constant; $M_{\mathrm{Si}}$ - the molar mass of $\mathrm{SiO}_{2} ; N_{A}$ - the Avogadro number; T-the absolute temperature, $\mathrm{K} ; A_{\mathrm{cr}}=4 \cdot \pi \times R_{\mathrm{c}}{ }^{2}$-critical nucleus surface area, $\mathrm{m}^{2} ; \Delta F_{\mathrm{cr}}=\sigma_{\mathrm{s}} \times A_{\mathrm{cr}} / 3=(16 \times \pi / 3) \times \sigma_{\mathrm{sw}}{ }^{3}\left(M_{\mathrm{SI}} / \rho \times N_{\mathrm{A}} \times k_{\mathrm{B}} \times T \times \ln S_{m}\right)^{2}$-change in free energy associated with the formation of a nucleus of critical radius $R_{\mathrm{c}} ; \rho$-density of amorphous silica, $\mathrm{kg} / \mathrm{m}^{3} ; \sigma_{\mathrm{sw}}$-surface tension at the silica-water interface, $\mathrm{J} / \mathrm{m}^{2} ; \mathrm{Z}$-Zeldovich factor.

$$
Z=\sqrt{-\frac{\partial^{2} \Delta F_{c r} / \partial n_{c r}^{2}}{2 \times \pi \times k_{B} \times T}}
$$

where $n_{c r}=(4 \times \pi / 3) \times\left(\rho \times N_{A /} M_{S i}\right) \times R_{c}{ }^{3}$-number of $\mathrm{SiO}_{2}$ molecules in the nucleus of critical size; $R_{c}=2 \times \sigma_{s w} \times M_{S i} /\left(\rho \times N_{A} \times k_{B} \times T \times \ln S_{m}\right)$ —critical radius; $\mathrm{Z}=(2 / 3) \times\left(3 /\left(4 \pi \times \rho \times n_{c r}{ }^{2}\right)\right)^{1 / 3} \times\left(\sigma_{\mathrm{sw}} / k_{\mathrm{B}}\right.$ $\times T)^{0.5} ; R_{M D}$ - the rate of molecular deposition of silicic acid $\left(\mathrm{g} \cdot \mathrm{cm}^{2} \cdot \mathrm{min}^{-1}\right)$, which determines the particle growth rate:

$$
R_{M D}=F\left(p H, p H_{\text {nom }}\right) \times k_{O H}(T) \times f_{f}\left(S_{a}\right) \times\left(1-S_{N}{ }^{-1}\right),
$$

where $\mathrm{k}_{\mathrm{OH}}(\mathrm{T}), \mathrm{F}\left(\mathrm{pH}, \mathrm{pH}_{\mathrm{nom}}\right), f_{f}\left(S_{a}\right)$-auxiliary functions depending on temperature, $\mathrm{pH}$, ionic strength $I_{s}$ and supersaturation $S_{m}$.

The characteristic polycondensation time - the temperature at which the supersaturation value decreased $e=2.71$ times from the initial one-was at $20^{\circ} \mathrm{C}$ and $\mathrm{pH}=8.5, \tau_{\mathrm{p}}=118.8 \mathrm{~min}$, and at $50{ }^{\circ} \mathrm{C}$, $\tau_{\mathrm{p}}=240.0 \mathrm{~min}$.

With a decrease in the polycondensation temperature and an increase in the initial supersaturation $S_{m}$, the nucleation $I_{N}$ rate increased and, accordingly, the final average diameter $d_{m}$ of $\mathrm{SiO}_{2}$ nanoparticles decreased, and the polycondensation of OSA passed faster. At $\mathrm{pH}=8.0-9.3$ and temperatures of $65-90{ }^{\circ} \mathrm{C}$, the $\mathrm{d}_{\mathrm{m}}$ values were $59-90 \mathrm{~nm}$, at $40-65^{\circ} \mathrm{C}, d_{m}=40-60 \mathrm{~nm}$, and at $20-40{ }^{\circ} \mathrm{C}, \mathrm{d}_{\mathrm{m}}=5-40 \mathrm{~nm}$.

After completion of the polycondensation of OSA and the growth of $\mathrm{SiO}_{2}$ nanoparticles, concentrated aqueous sols were obtained by three-stage ultrafiltration membrane concentration. At the first stage, the $\mathrm{SiO}_{2}$ content in the sol was increased from 0.05 to $0.3-0.4 \mathrm{wt} . \%$, at the second stage it increased up to $10 \mathrm{wt} . \%$, on the third it increased up to $20 \%$ to $40 \mathrm{wt} . \%$. The capillary type ultrafiltration membrane cartridge had an internal capillary diameter of $0.8 \mathrm{~mm}$, a filter surface area of $55 \mathrm{~m}^{2}$, a minimum mass weight cut off parameter $\mathrm{MWCO}=10-100 \mathrm{kD}$, a pressure drop across the membrane layer of $0.025-0.4 \mathrm{MPa}$, and permeability membranes $(0.025-0.8) \mathrm{m}^{3} / \mathrm{m}^{2} \cdot \mathrm{h} \cdot \mathrm{MPa}$. The final $\mathrm{SiO}_{2}$ content in sols was brought to $100.0-600.0 \mathrm{~g} / \mathrm{dm}^{3}=10-40 \mathrm{wt} . \%$, salinity TDS $=800-2000 \mathrm{mg} / \mathrm{dm}^{3}$, 
specific conductivity $0.8-1.56 \mathrm{mS} / \mathrm{cm}$, and dynamic viscosity $1-120 \mathrm{MPa} \cdot \mathrm{s}\left(20^{\circ} \mathrm{C}\right)$. The choice of pore sizes of polymer ultrafiltration membranes $(\mathrm{MWCO}=10-100 \mathrm{kD})$ can provide high selectivity for $\mathrm{SiO}_{2}$ nanoparticles and low selectivity for ions of dissolved salts. Therefore, the parameter $m_{s}=\left[\mathrm{SiO}_{2}\right] / \mathrm{TDS}$ continuously increases with increasing $\mathrm{SiO}_{2}$ content (up to 300 and higher), the inverse parameter $\left(1 / m_{s}\right)$ decreases to 0.003 and lower, and there was no accumulation of ions in the concentrate. As a result, the value of the zeta potential of the surface of nanoparticles in concentrated sols fell in the range from -56 to $-25 \mathrm{mV}$, which ensured the stability of particles to aggregation due to electrostatic repulsion without forced incorporation of stabilizers with $\mathrm{SiO}_{2}$ content up to $62.5 \mathrm{wt}$.\%. Figure 1 shows the results of dynamic light scattering determination of the diameter distribution of particle volume for a sol sample with a content of $\mathrm{SiO}_{2}=178 \mathrm{~g} / \mathrm{dm}^{3}, \mathrm{pH}=9.0$, the average diameter of $\mathrm{SiO}_{2}$ particles in volume $d_{m}=8.5 \mathrm{~nm}$. The average value of the zeta potential of the particle surface found by the method electrophoretic light scattering was $\xi_{m}=-42.0 \mathrm{mV}$ (Zetasizer, Malvern, UK).

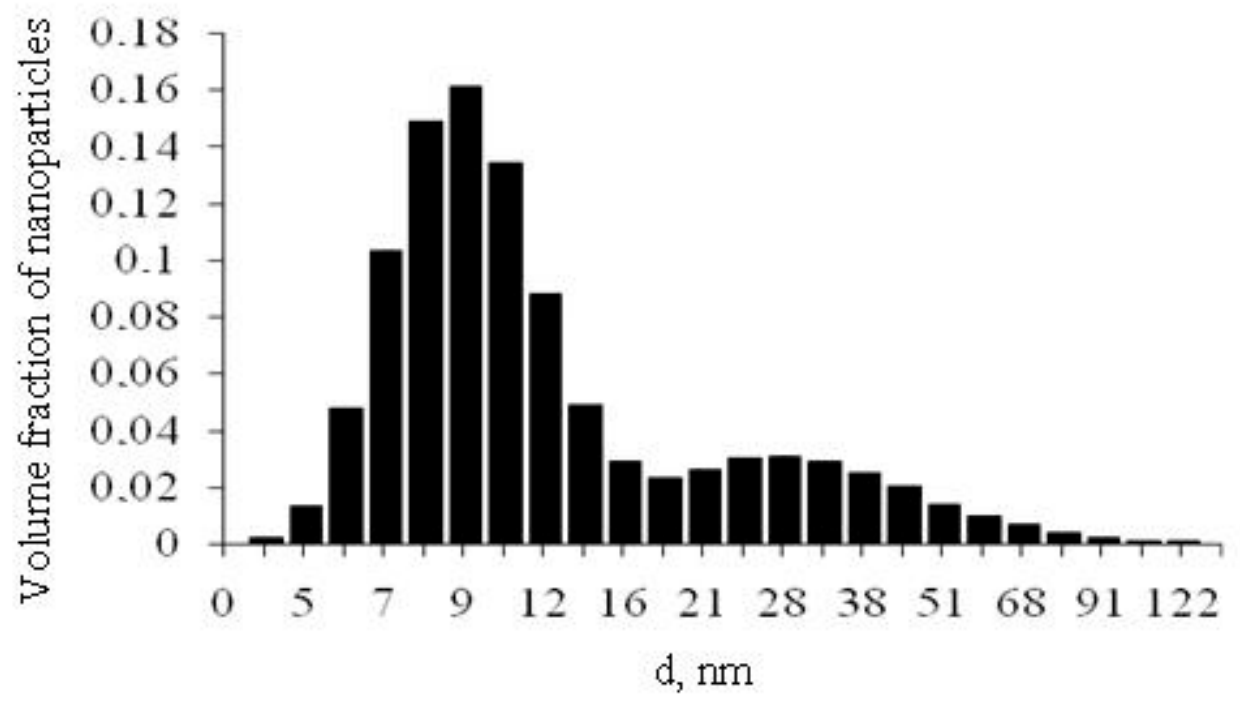

Figure 1. The particle sizes distribution in the hydrothermal sol sample, determined by dynamic light scattering.

$\mathrm{SiO}_{2}$ nanopowders were obtained using cryochemical vacuum sublimation of sols. Cryochemical technology includes a sequence of main stages:

(1) Dispersion of the sol and cryocrystallization of droplets of a dispersed medium;

(2) sublimation of the solvent from the cryogranulate obtained in the previous step;

(3) desublimation of the solvent.

The cryochemical setup is shown in Figures 2 and 3.

Before sublimation in a vacuum chamber, silica sols were dispersed using a nozzle, the droplets were solidified in liquid nitrogen at a temperature of $77 \mathrm{~K}$, and cryogranules were obtained. After dispersion, the droplet size was 20 to $100 \mu \mathrm{m}$, the corresponding average droplet cooling rate was about $125 \mathrm{~K} / \mathrm{s}$, and the crystallization rate was $0.26 \mathrm{~mm} / \mathrm{s}$. The small size of the sol droplets and the high heat transfer surface made it possible to achieve rapid hardening of the droplets and the absence of particle adhesion. The particle sizes in the powders did not exceed the particle sizes in the sols. Vacuum sublimation took place at pressures from 0.02 to $0.05 \mathrm{~mm} \mathrm{Hg}$ without fragments of droplet moisture and particles sticking together (Figure 4). To accelerate sublimation, heating was used. The temperature range of the heating surfaces in different parts of the vacuum chamber as it was heated during sublimation ranged from -80 to $+25^{\circ} \mathrm{C}$ (Figure 5). Productivity of the unit with a power consumption from 3 to $5 \mathrm{~kW}$ is $0.15-0.20 \mathrm{~L} / \mathrm{h}$. The residual water content in nanopowders was adjusted to $0.2 \mathrm{wt} . \%$ 


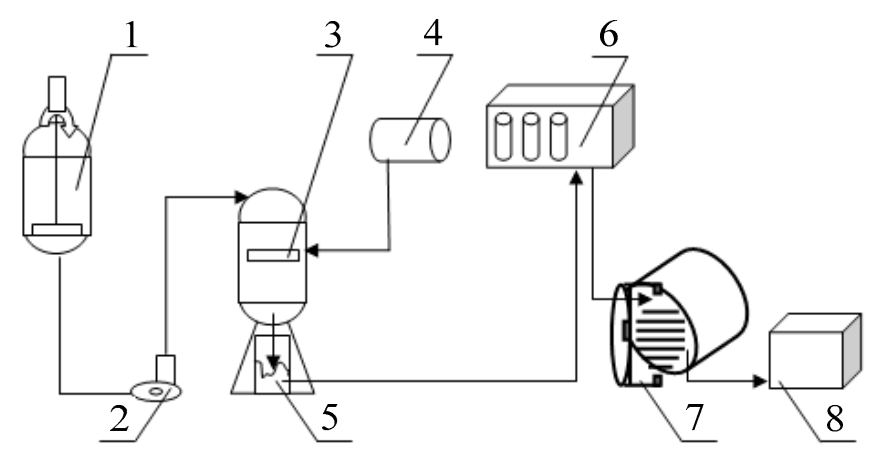

Figure 2. Scheme of the cryochemical vacuum sublimation setup for producing $\mathrm{SiO}_{2}$ nanopowder: 1-apparatus for the preparation of an aqueous sol; 2-metering pump; 3 -cryogranulator; 4 -tanker with liquid nitrogen; 5-capacity for storing cryogranules; 6-refrigerator; 7-sublimation apparatus; 8-box for storing nanopowder samples.

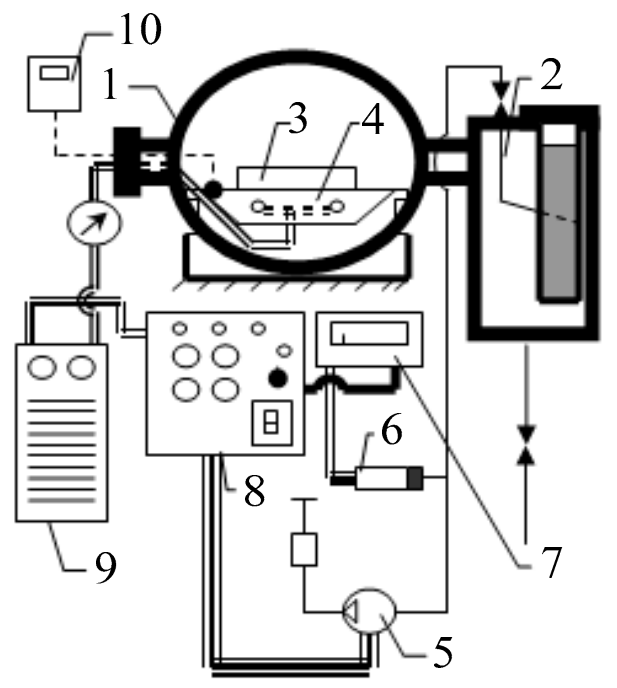

Figure 3. Vacuum sublimation apparatus: 1—sublimation chamber; 2 -desublimator; 3 -tray with a product; 4-heating stove; 5-vacuum pump; 6-gauge thermocouple; 7-vacuum gauge; 8-control panel; 9-universal voltage regulator, 10-electronic thermometer.

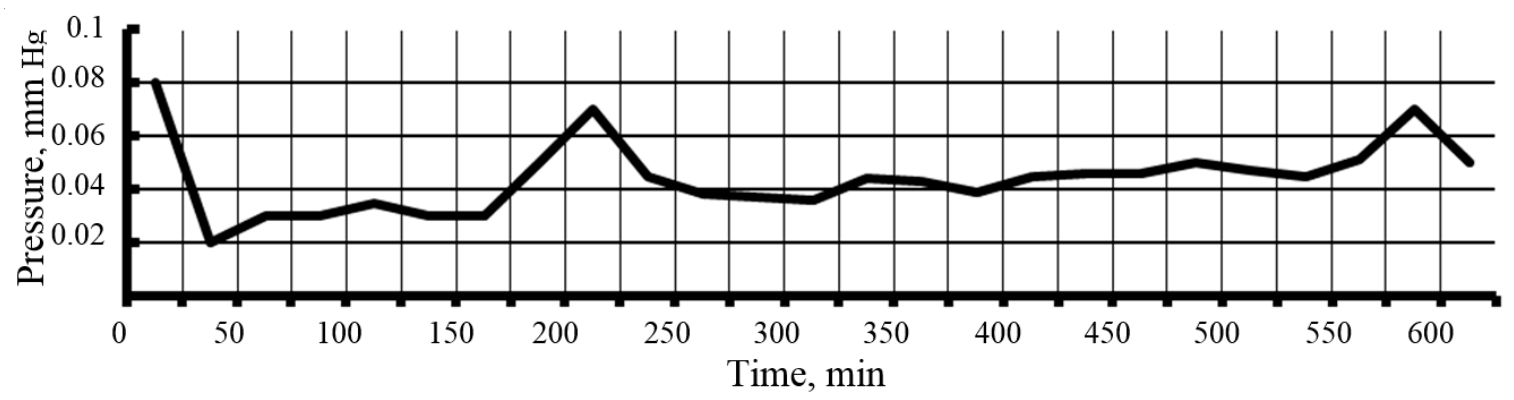

Figure 4. Dependence of pressure on time during sublimation upon receipt of a sample of nanopowder. 


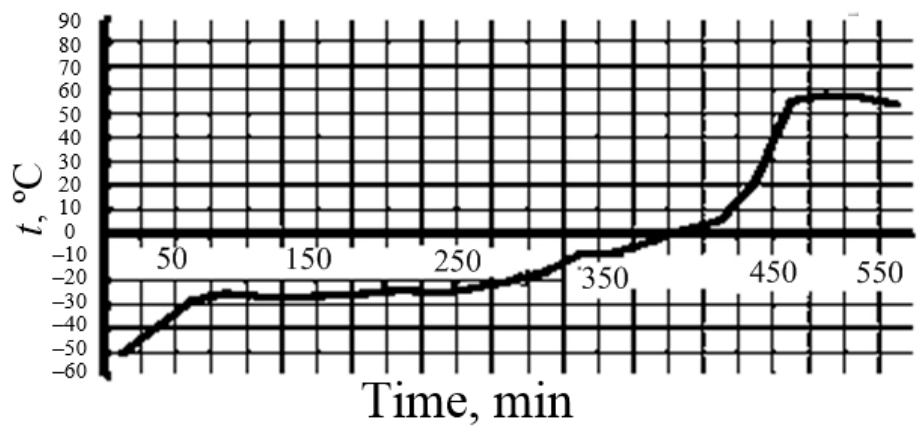

Figure 5. Dependence of temperature $t$ in a vacuum chamber on the time of sublimation of cryogranules upon receipt of a nanopowder sample.

\subsection{Research Methods}

The spherical shape of nanopowder particles was confirmed by TEM images obtained with a transmission electron microscope JEM-100CX, JEOL, Hiroshima, Tokyo, Japan.

Pour density of uncompacted nanopowders were measured using a PT-SV100 Scott volumeter (Pharma Test Apparatebau AG, Germany) with a system of alternating inclined shelves for "transfusion" of samples in the volume for weighing along a S-shaped path, which ensured the uniform distribution of nanopowders.

By the method of low-temperature nitrogen adsorption (ASAP-2010, Micromeritics Instrument Corporation, Norcross, GA, USA), adsorption-desorption curves were obtained. According to the adsorption-desorption curves for samples of nanopowders calculated the:

- BET area;

- specific surface areas, specific volumes, average diameters at one point and along the curves of adsorption and desorption of the area (BJH method);

- differential and integral distribution of area and volume over pore diameters;

- specific areas and volumes of micropores were found (with a diameter of less than $2 \mathrm{~nm}$ ).

The amorphous structure of nanopowders was established by $\mathrm{X}$-ray diffraction analysis (ARL X'TRA, Thermo Scientific, Basel, Switzerland).

Using small-angle X-ray scattering (SAXS), the dependences of the scattered radiation intensity function on the wave scattering vector were established (RigakuUltima IV, Rigaku Americas Corporation, Woodlands, TX, USA, rotating Cu anode, X-ray wavelength - $1.54 \AA$ ).

To determine the concentration of impurity components in nanopowders, a S4 PIONEER X-ray fluorescence spectrometer (Bruker, $\mathrm{GmbH}$, Bremen, Germany) was used. Thermogravimetric analysis and estimation of mass losses during heating of the nanopowder were performed on a Pyris Diamond TG/DTA derivatograph (PerkinElmer LLC, Norwalk, CT, USA).

For determining compressive strength of the samples of compacted nanopowders servohydravlic machine Shimadzu AGS-X (Shimadzu Corporation, Japan) was used.

\section{Results}

\subsection{SEM Images}

According to scanning electron microscopy images with magnification factors equal to 250-7000, the sizes of the structures formed because of vacuum sublimation cryogranules of sols were within 20.0 to $100.0 \mu \mathrm{m}$. Figure 6 shows images of powder structures after sublimation of the solvent with a successively increasing coefficient of increase of $247,500,800,1000,2500$, and 7000 times. After removal of the solvent, a porous-mesh structure of powder particles remains, preserving the features of a spherical shape and the size of solid cryogranule. Cavities formed inside the residual structures in their central part after solvent removal, which indicates the hardening mechanism of a sol drop of 
water removal from solid cryogranules. With light exposure, the residual structures were destroyed, forming flakes with a thickness of 0.1 to $0.2 \mu \mathrm{m}$.

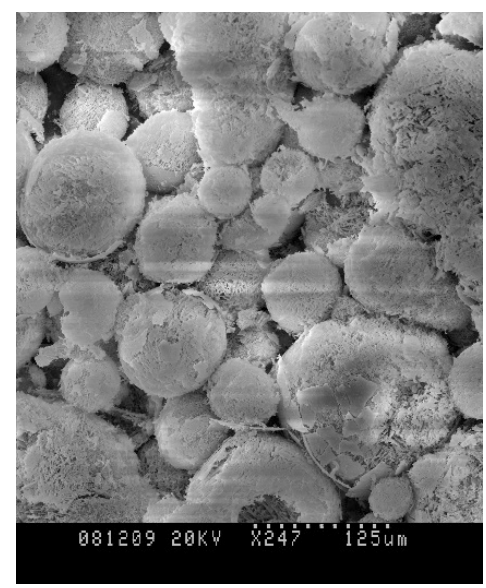

(a)

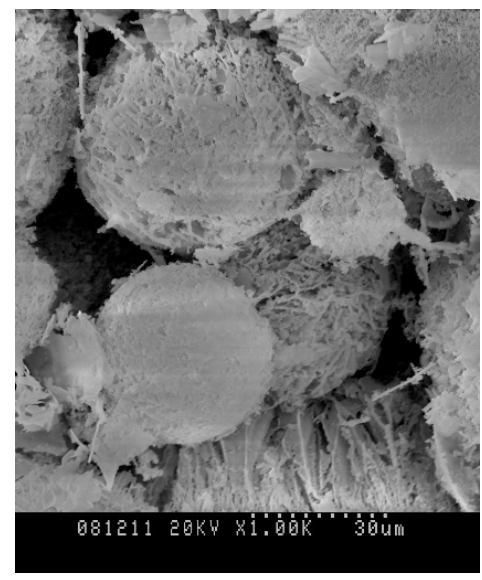

(d)

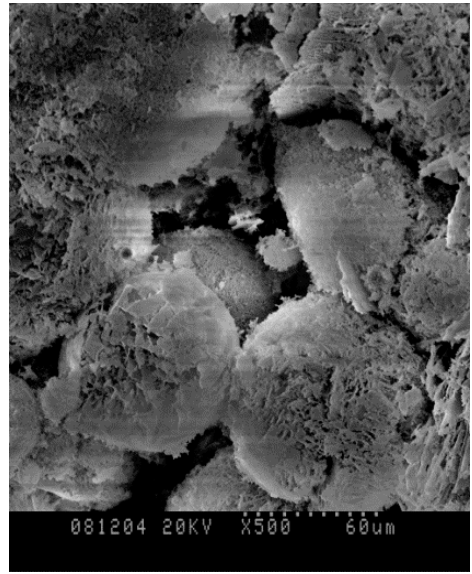

(b)

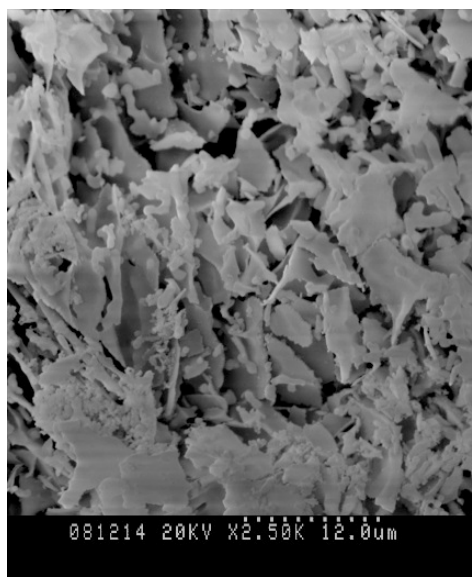

(e)

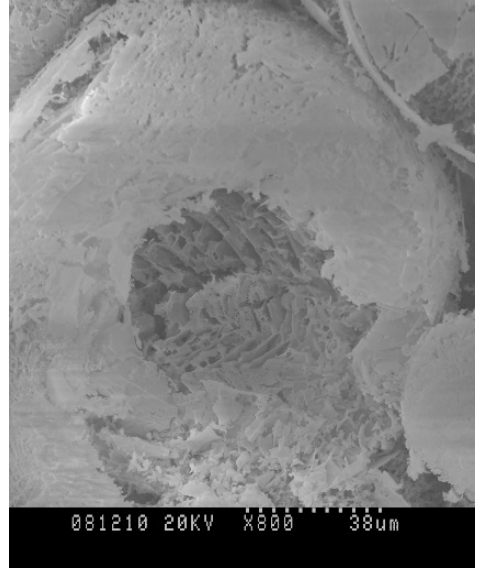

(c)

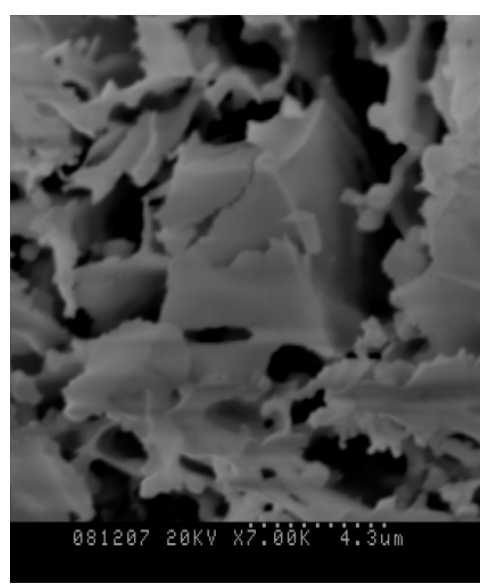

(f)

Figure 6. Images of structures from silica powder particles formed after sublimation of the solvent from cryogranules. The magnification factors on a scanning electron microscope: (a) 247 times; (b) 500 times; (c) 600 times; (d) 1000 times; (e) 2500 times; (f) 7000 times.

Figure 7 shows the images of nanopowder particles obtained by transmission electron microscopy (TEM) (the content of $\left[\mathrm{SiO}_{2}\right]$ in the sol before sublimation is $100 \mathrm{~g} / \mathrm{dm}^{3}$ ).

\subsection{Pour Density of $\mathrm{SiO}_{2}$ Nanopowders}

Table 2 and Figure 8 show the dependence of the pour density of powders $\rho_{p}$ on the content of $\left[\mathrm{SiO}_{2}\right]$ in sols. When the content of $\left[\mathrm{SiO}_{2}\right]$ in sols was from 2.4 to $90 \mathrm{~g} / \mathrm{dm}^{3}$, the density $\rho_{\mathrm{p}}$ after sublimation of water molecules from cryogranules and replacing them with air molecules was higher than the content of $\mathrm{SiO}_{2}$ in sols. Accordingly, after the sublimation of water molecules, the volume concentration of $\mathrm{SiO}_{2}$ nanoparticles in the nanopowder increased compared to the sol, and the average distance between the particles decreased. Therefore, at $\left[\mathrm{SiO}_{2}\right]=2.4 \mathrm{~g} / \mathrm{dm}^{3}, \rho_{\mathrm{p}}$ was $20.5 \mathrm{~g} / \mathrm{dm}^{3}$. When the content of $\left[\mathrm{SiO}_{2}\right]$ in sols was higher than $90 \mathrm{~g} / \mathrm{dm}^{3}$ after sublimation of water molecules, the concentration of $\mathrm{SiO}_{2}$ nanoparticles in the volume with air molecules decreased, and $\rho_{\mathrm{p}}$ became lower than $\left[\mathrm{SiO}_{2}\right]$ : at $\left[\mathrm{SiO}_{2}\right]=520 \mathrm{~g} / \mathrm{dm}^{3}, \rho_{\mathrm{p}}=274 \mathrm{~g} / \mathrm{dm}^{3}$. Accordingly, after sublimation of water molecules, the volume concentration of $\mathrm{SiO}_{2}$ nanoparticles decreased, and the average distance between particles increased. The $\rho_{\mathrm{p}} /\left[\mathrm{SiO}_{2}\right]$ ratio decreased with increasing $\left[\mathrm{SiO}_{2}\right]$ content in sols from 8.5 to 0.53 , 
while in the range of $\left[\mathrm{SiO}_{2}\right]=100-520 \mathrm{~g} / \mathrm{dm}^{3}$ it was changing relatively little: from 0.75 to 0.53 . In the range of $\left[\mathrm{SiO}_{2}\right]$ contents in sols from 100 to $520 \mathrm{~g} / \mathrm{dm}^{3}$, the $\rho_{\mathrm{p}}\left(\left[\mathrm{SiO}_{2}\right]\right)$ dependence was close to linear.

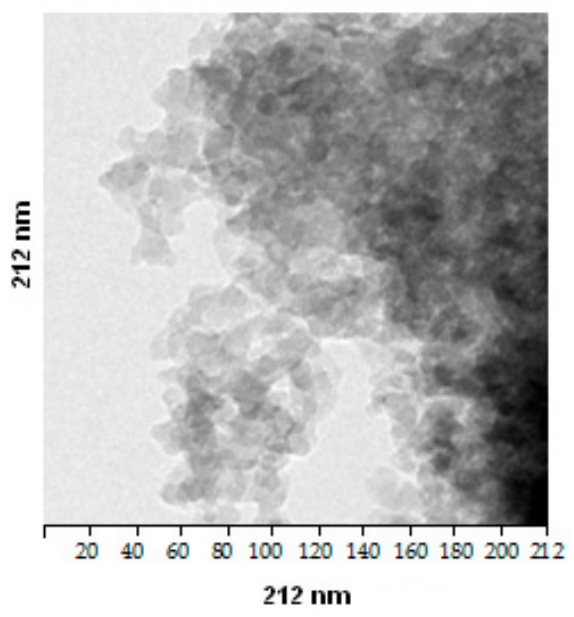

(a)

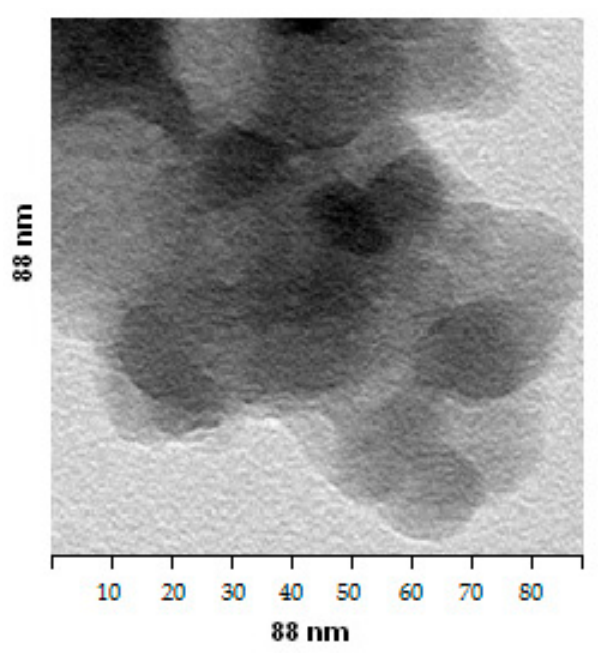

(b)

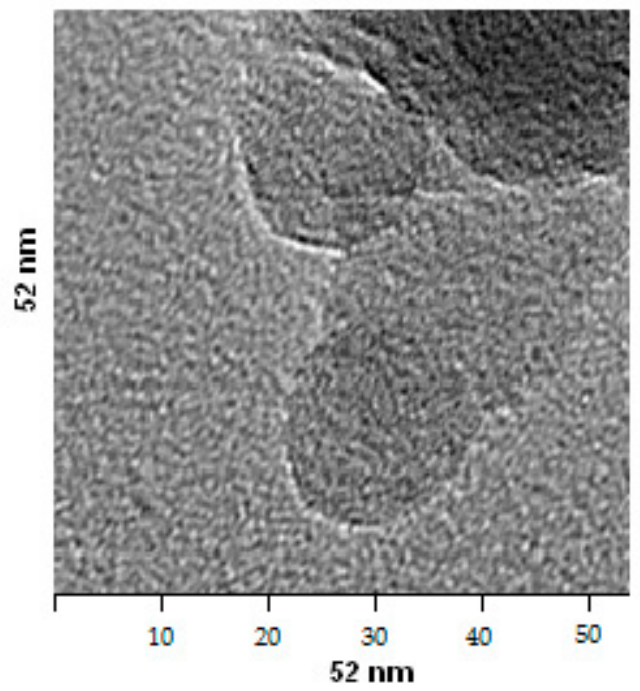

(c)

Figure 7. TEM images of $\mathrm{SiO}_{2}$ nanopowder particles obtained by tunneling electron microscopy. Dimensions of the image area of $\mathrm{SiO}_{2}$ particles: (a) $212 \times 212 \mathrm{~nm}^{2}$; (b) $88 \times 88 \mathrm{~nm}^{2}$; (c) $52 \times 52 \mathrm{~nm}^{2}$.

Table 2. Pour density of nanopowders, $\rho_{p}$, depending on the $\mathrm{SiO}_{2}$ content in the sol.

\begin{tabular}{ccccccccccccc}
\hline$\left[\mathrm{SiO}_{2}\right], \mathbf{g} / \mathbf{d m}^{3}$ & 2.4 & 5.2 & 6.93 & 10.4 & 17.56 & 32 & 65.85 & 120 & 131.7 & 160 & 260 & 520 \\
\hline$\rho_{p}, \mathbf{g} / \mathbf{d m}^{3}$ & 20.5 & 29 & 35 & 43.8 & 55 & 55 & 84 & 91 & 100 & 117 & 168 & 274 \\
\hline$\rho_{\mathrm{p}} /\left[\mathrm{SiO}_{2}\right]$ & 8.5 & 5.6 & 5.05 & 4.21 & 3.13 & 1.71 & 1.27 & 0.76 & 0.76 & 0.73 & 0.65 & 0.53 \\
\hline
\end{tabular}

\subsection{Pore Characteristics of Nanopowders Obtained by Cryochemical Vacuum Sublimation of $\mathrm{SiO}_{2} \mathrm{Sols}_{\mathrm{S}}$}

Table 3 shows the characteristics of the pores of powder samples established by low-temperature nitrogen adsorption. The characteristics of the samples are given in order of increasing values of their BET area $S_{\text {BET }}$. Figures 9-11, for five of the samples in Table 3, in an ascending order of $S_{\text {BET }}$, show graphs of nitrogen adsorption-desorption isotherms, differential and integral distributions of pore area and volume over diameters. 
Table 3. Pore characteristics of powders established by low-temperature nitrogen adsorption.

\begin{tabular}{|c|c|c|c|c|c|c|c|c|c|c|c|c|c|c|}
\hline Sample ID & $\begin{array}{l}{\left[\mathrm{SiO}_{2}\right],} \\
\mathrm{g} / \mathrm{dm}^{3}\end{array}$ & $\begin{array}{c}\rho_{\mathrm{p}}{ }^{3} \\
\mathrm{~g} / \mathrm{dm}^{3}\end{array}$ & $\begin{array}{l}\mathrm{S}_{\mathrm{BET},} \\
\mathrm{m}^{2} / \mathrm{g}\end{array}$ & $\begin{array}{c}\text { Pore area by } \\
\text { adsorption } \\
\text { curve }(\mathrm{BJH}), \\
\mathrm{S}_{\mathrm{BET}_{,}, \mathrm{m}^{2} / \mathrm{g}}\end{array}$ & $\begin{array}{c}\text { Pore area by } \\
\text { desorption } \\
\text { curve (BJH), } \\
\mathrm{m}^{2} / \mathrm{g}\end{array}$ & $\begin{array}{l}\text { Single point } \\
\text { pore volume, } \\
\mathbf{v}_{\mathrm{p}}, \mathrm{cm}^{3} / \mathrm{g}\end{array}$ & $\begin{array}{l}\text { Pore volume by } \\
\text { adsorption curve } \\
(\mathrm{BJH}), \mathrm{cm}^{3} / \mathrm{g}\end{array}$ & $\begin{array}{c}\text { Pore volume } \\
\text { by } \\
\text { desorption } \\
\text { curve }(\mathrm{BJH}) \\
\mathrm{cm}^{3} / \mathrm{g}\end{array}$ & $\mathrm{d}_{\mathrm{BET}, \mathrm{nm}}$ & $\begin{array}{l}\text { Average pore } \\
\text { diameter, } \\
\mathrm{d}_{\mathrm{p}}, \mathrm{nm}\end{array}$ & $\begin{array}{c}\text { Average pore } \\
\text { diameter by } \\
\text { adsorption } \\
\text { curve, } \mathrm{nm}\end{array}$ & $\begin{array}{c}\text { Average pore } \\
\text { diameter by } \\
\text { desorption } \\
\text { curve, nm }\end{array}$ & $\begin{array}{c}\text { Area of } \\
\text { micropores, } \\
\mathrm{m}^{2} / \mathrm{g}\end{array}$ & $\begin{array}{c}\text { Volume of } \\
\text { micropores, } \\
\mathrm{cm}^{3} / \mathrm{g}\end{array}$ \\
\hline UF-1-9 & 128.0 & 86 & 45.4 & 35.6 & 37.7 & 0.10 & 0.23 & 0.237 & 60 & 9.4 & 26.4 & 25.1 & 2.18 & d.n. \\
\hline UF-2-32 & 233.8 & 229 & 56.8 & 47.0 & 51.8 & 0.15 & 0.19 & 0.19 & 48.0 & 10.9 & 16.6 & 15.2 & 5.6 & 0.001 \\
\hline UF-3-8 & 24.4 & 52 & 62.0 & 48.3 & 58.0 & 0.19 & 0.24 & 0.25 & 44.0 & 12.6 & 20.5 & 17.3 & 11.4 & 0.004 \\
\hline UF-4-34 & 586.9 & 344 & 74.0 & 63.9 & 69.7 & 0.18 & 0.19 & 0.20 & 36.8 & 10.0 & 12.4 & 11.6 & 5.0 & 0.001 \\
\hline UF-5-25 & 108.9 & 52 & 97.7 & 78.8 & 90.4 & 0.22 & 0.26 & 0.27 & 27.9 & 9.4 & 13.5 & 11.9 & 13.9 & 0.005 \\
\hline UF-6-26 & 114.5 & 90 & 120.4 & 111.4 & 121.2 & 0.21 & 0.22 & 0.23 & 22.6 & 7.0 & 8.2 & 7.6 & 8.9 & 0.002 \\
\hline UF-7-17 & 28.0 & 35 & 166.5 & 151.4 & 162.1 & 0.25 & 0.28 & 0.28 & 16.4 & 6.2 & 7.5 & 7.1 & 8.2 & 0.001 \\
\hline UF-8-21 & 14.0 & 15.7 & 200.8 & 158.1 & 166.6 & 0.20 & 0.22 & 0.23 & 13.6 & 4.0 & 5.8 & 5.5 & 10.8 & 0.001 \\
\hline UF-9-43 & 170.9 & 231.7 & 209.9 & 199.6 & 239.1 & 0.21 & 0.20 & 0.22 & 13.0 & 4.0 & 4.0 & 4.0 & 0.1 & d.n. \\
\hline UF-10-3 & 82.5 & 90.0 & 316.0 & 272.1 & 289.9 & 0.243 & 0.216 & 0.221 & 8.6 & 3.0 & 3.2 & 3.0 & d.n. & d.n. \\
\hline UF-11-20 & 33.2 & 58 & 360.4 & 256.9 & 280.8 & 0.301 & 0.280 & 0.290 & 7.56 & 3.3 & 4.2 & 4.1 & 33.8 & 0.010 \\
\hline UF-12-16 & 66.0 & 86 & 476.3 & 354.3 & 367.1 & 0.32 & 0.26 & 0.27 & 5.72 & 2.70 & 3.0 & 2.94 & 0.1 & d.n. \\
\hline
\end{tabular}

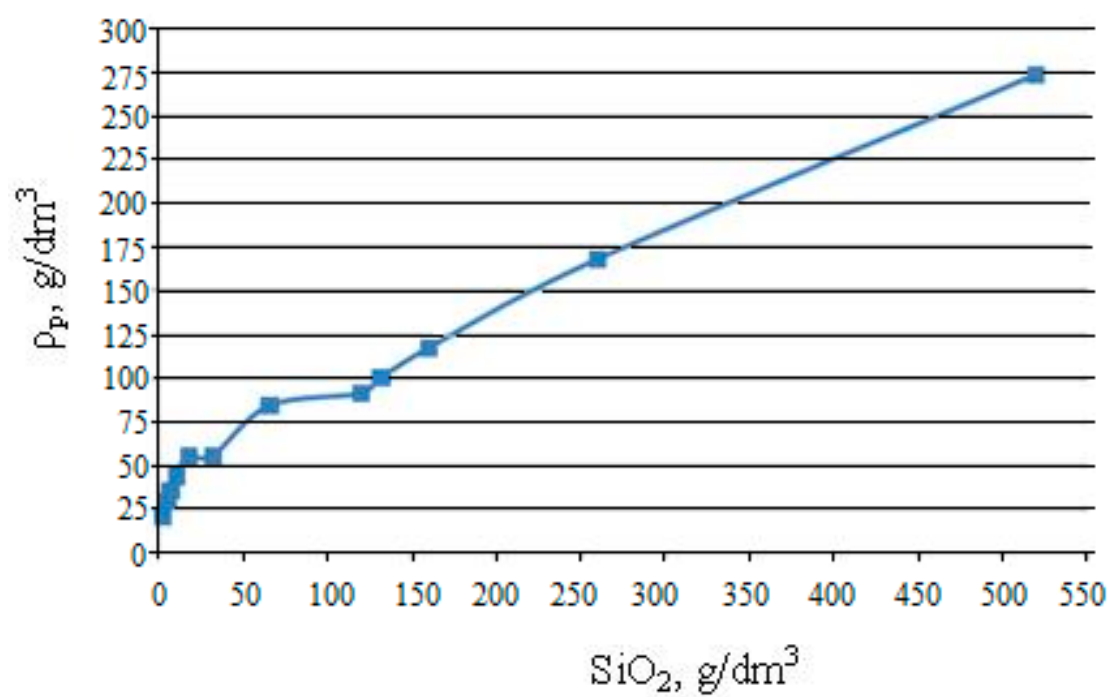

Figure 8. Dependence of the pour density of the nanopowder on the content of $\mathrm{SiO}_{2}$ in the sol. 


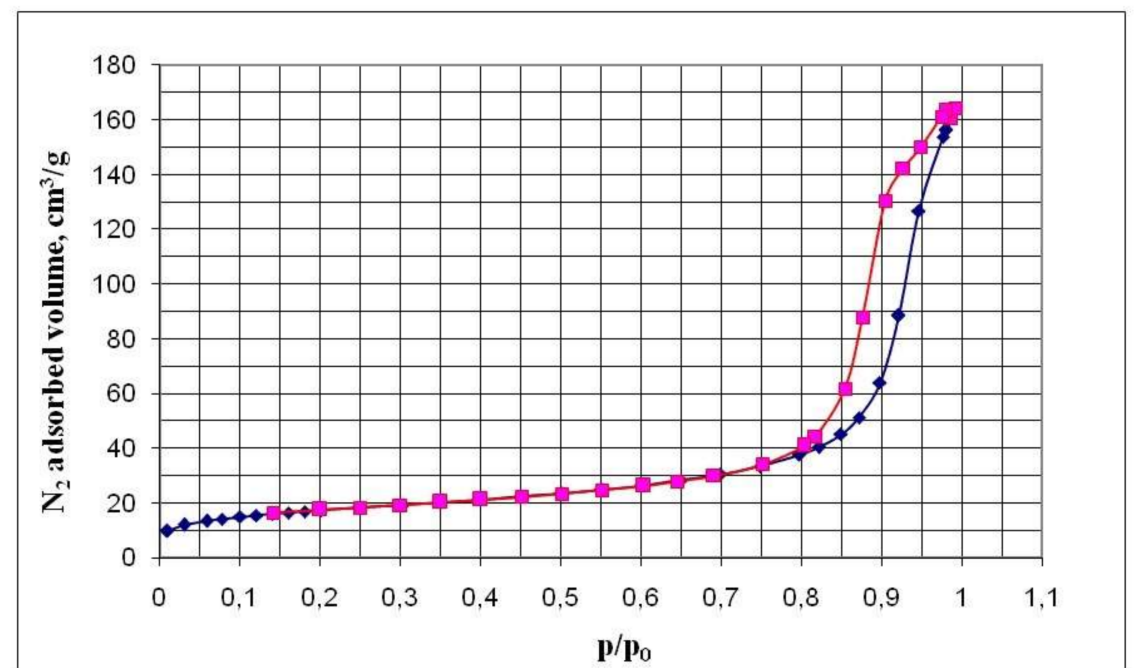

(a)

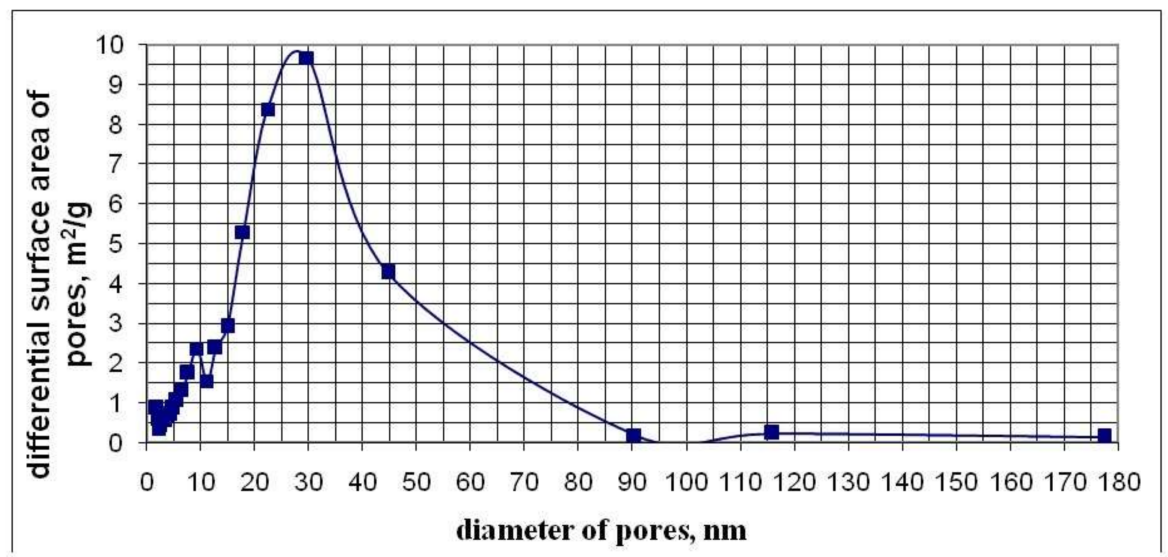

(b)

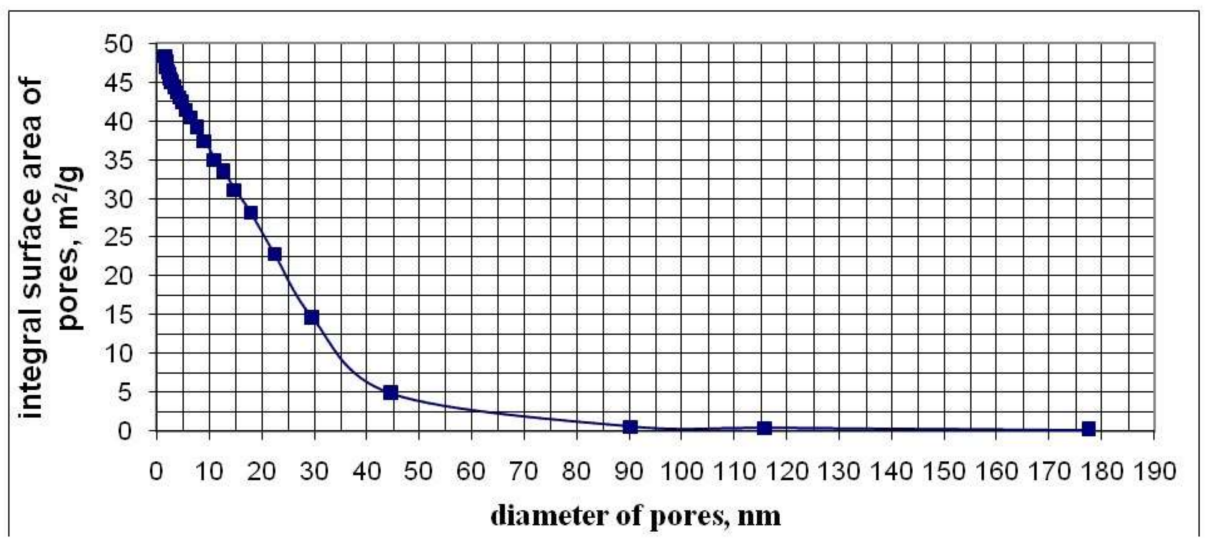

(c)

Figure 9. Cont. 


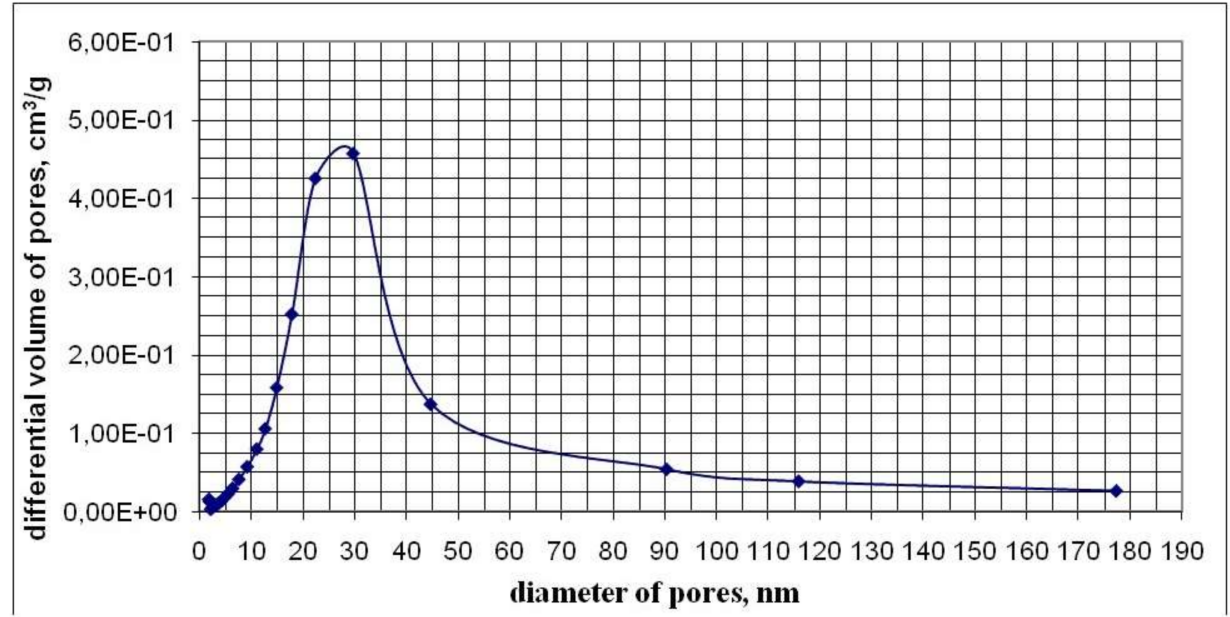

(d)

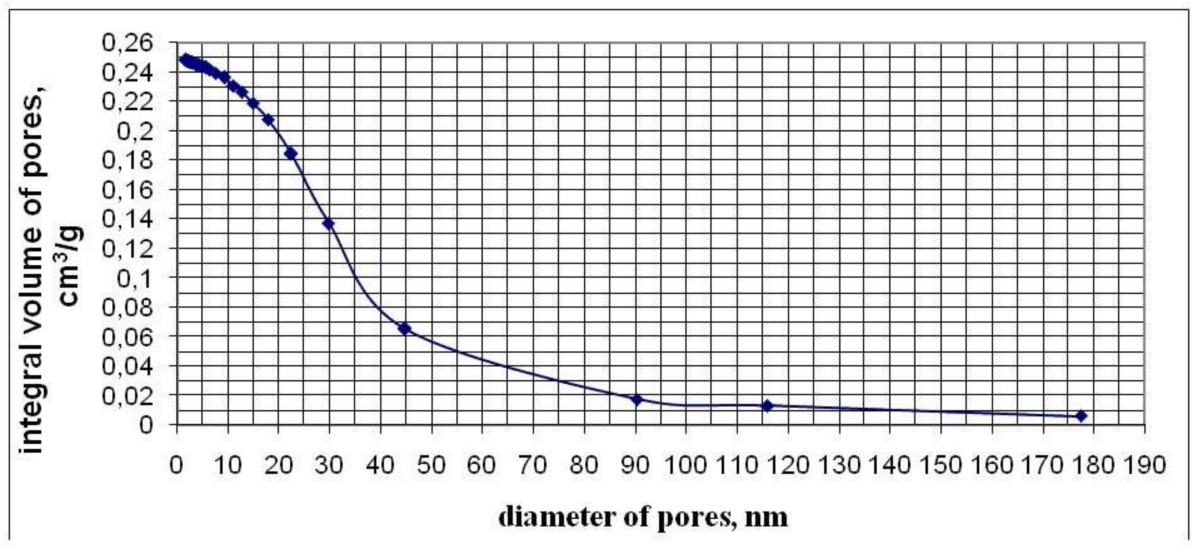

(e)

Figure 9. Pore characteristics of the UF-3-8 sample obtained by the low-temperature nitrogen adsorption method: (a) adsorption-desorption curves ( $\mathrm{p} / \mathrm{p}_{0}$-relative nitrogen pressure, $\mathrm{p}_{0}$-nitrogen saturation pressure at a temperature of $77 \mathrm{~K}$ ); (b) differential distribution of area over pore diameter; (c) integral distribution of the area along the pore diameter; (d) xifferential distribution of volume over pore diameter; (e) integral distribution of volume by pore diameter.

Nitrogen sorption-desorption isotherms are of type IV and have a hysteresis loop characteristic of mesopores with diameters from 2 to $50 \mathrm{~nm}$ and allow one to estimate the pore size distribution. Hysteresis on the isotherm graph allows us to conclude that nanopowders are a globular system consisting of spherical particles, each of which is in contact with two or more neighboring particles. By lowering the temperature of the hydrothermal solution at the OSA polycondensation stage from 90 to $20^{\circ} \mathrm{C}$, a decrease in the sizes of $\mathrm{SiO}_{2}$ particles was achieved. Additionally, there was an increase in their specific surface area and a decrease in the average pore diameter;

$$
d_{p}=4 \times V_{p} / S_{B E T}
$$




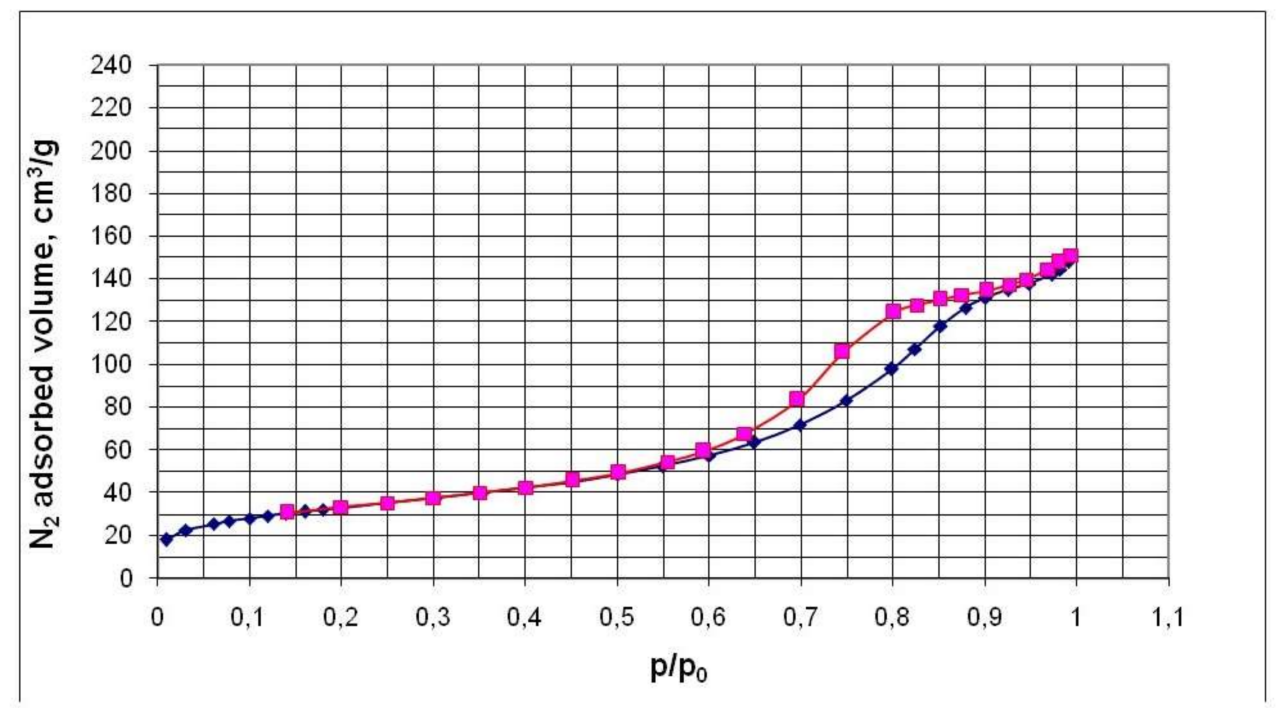

(a)

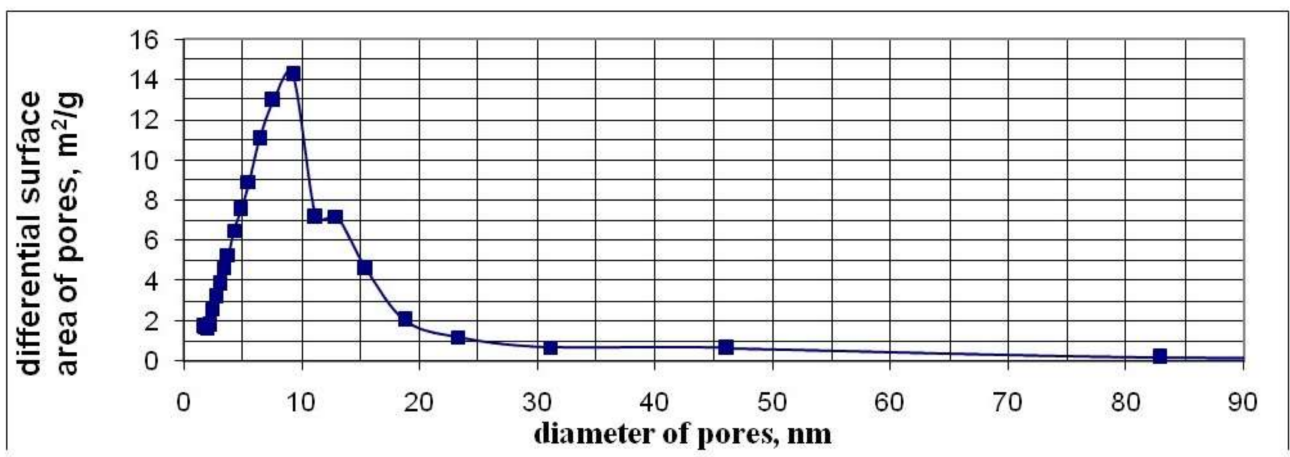

(b)

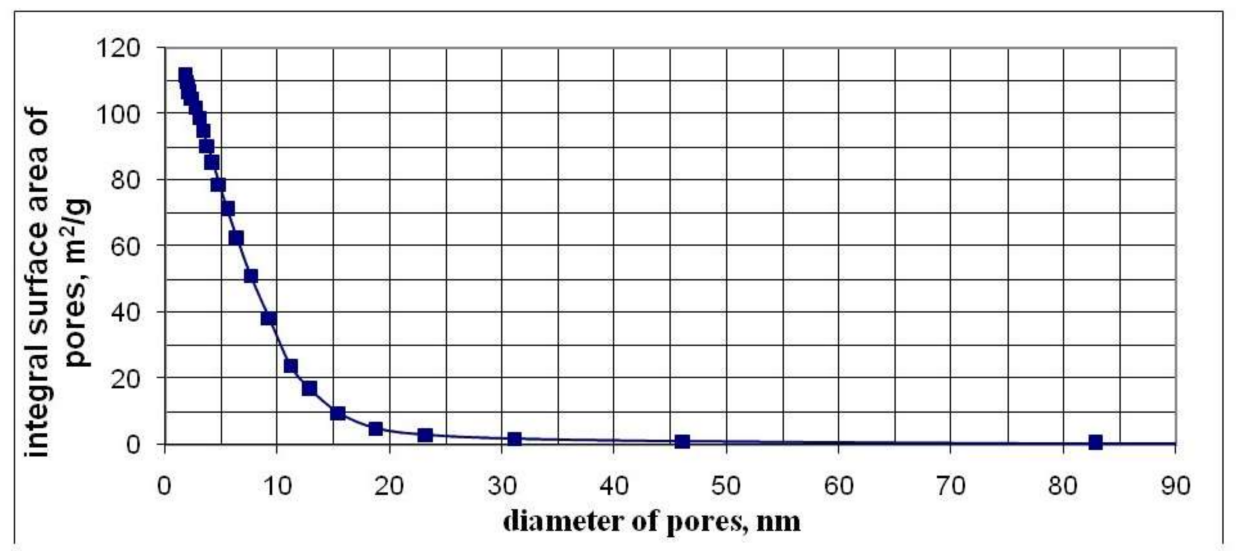

(c)

Figure 10. Cont. 


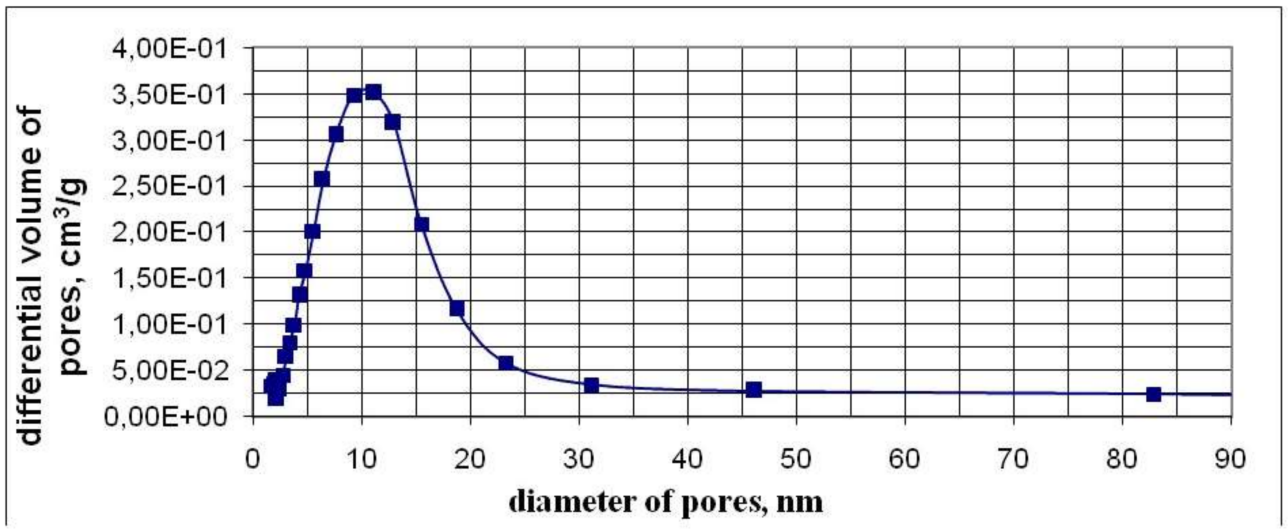

(d)

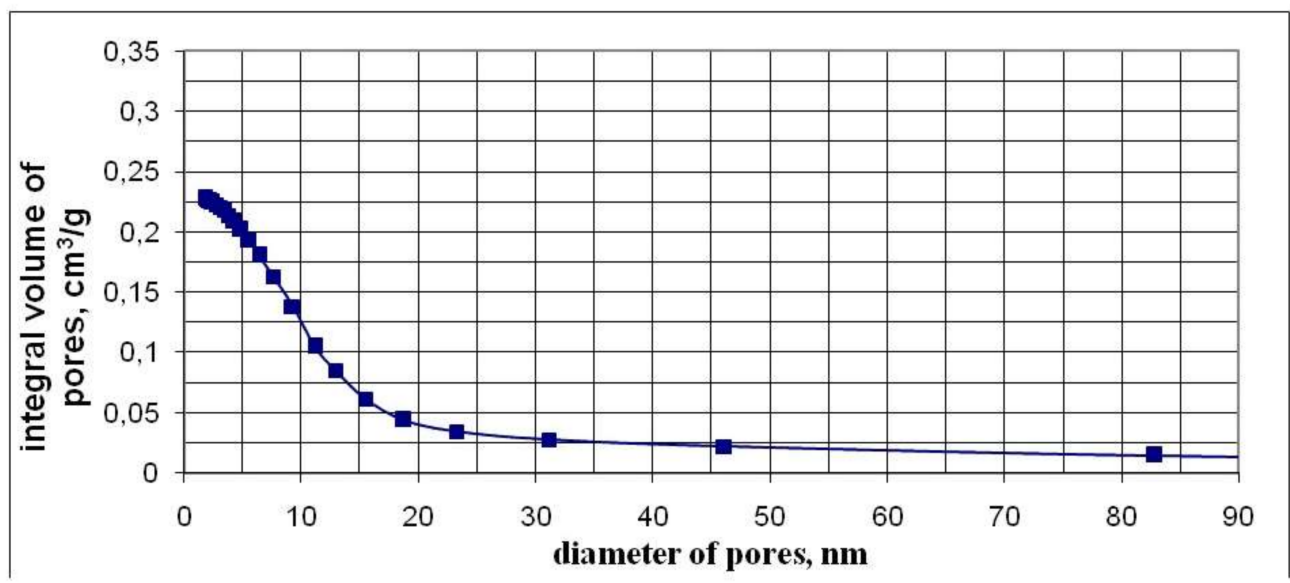

(e)

Figure 10. Pore characteristics of the UF-6-26 sample obtained by the low-temperature nitrogen adsorption method: (a) adsorption-desorption curves $\left(\mathrm{p} / \mathrm{p}_{0}\right.$-relative nitrogen pressure, $\mathrm{p}_{0}$ - nitrogen saturation pressure at a temperature of $77 \mathrm{~K}$ ); (b) differential distribution of area over pore diameter; (c) integral distribution of the area along the pore diameter; (d) differential distribution of volume over pore diameter; (e) integral distribution of volume by pore diameter.

With a temperature decrease at the OSA polycondensation to $20^{\circ} \mathrm{C}$, the BET-nanopowder area was regulated and increased to $500 \mathrm{~m}^{2 /} \mathrm{g}$. In this case, the specific pore volume $V_{p}$ was in a narrow range of 0.20 to $0.30 \mathrm{~cm}^{3} / \mathrm{g}$ and the average pore size decreased to $2.7 \mathrm{~nm}$ (Table 3). The specific pore volume $V_{p}$ depended weakly on the density of nanopowders.

The specific pore volume $V_{p}=0.20-0.30 \mathrm{~cm}^{3} / \mathrm{g}$ showed that spherical $\mathrm{SiO}_{2}$ particles form aggregates with a high-volume fraction. The volume fraction of $\mathrm{SiO}_{2}$ particles with a density of $2.2 \mathrm{~g} / \mathrm{cm}^{3}$ in aggregates at $V_{p}=0.20-0.30 \mathrm{~cm}^{3} / \mathrm{g}$ was $V_{s} / V_{a g g r}=0.7-0.6\left(V_{s}\right.$ is the volume of $\mathrm{SiO}_{2}$ particles occupied in the aggregate, $V_{\text {aggr }}$ is the aggregate volume), the density of the substance in aggregates was 1.32 to $1.54 \mathrm{~g} / \mathrm{cm}^{3}$. The density of the substance in the aggregates was much higher than the density of nanopowders $\rho_{p}=0.02-0.274 \mathrm{~g} / \mathrm{cm}^{3}$. 


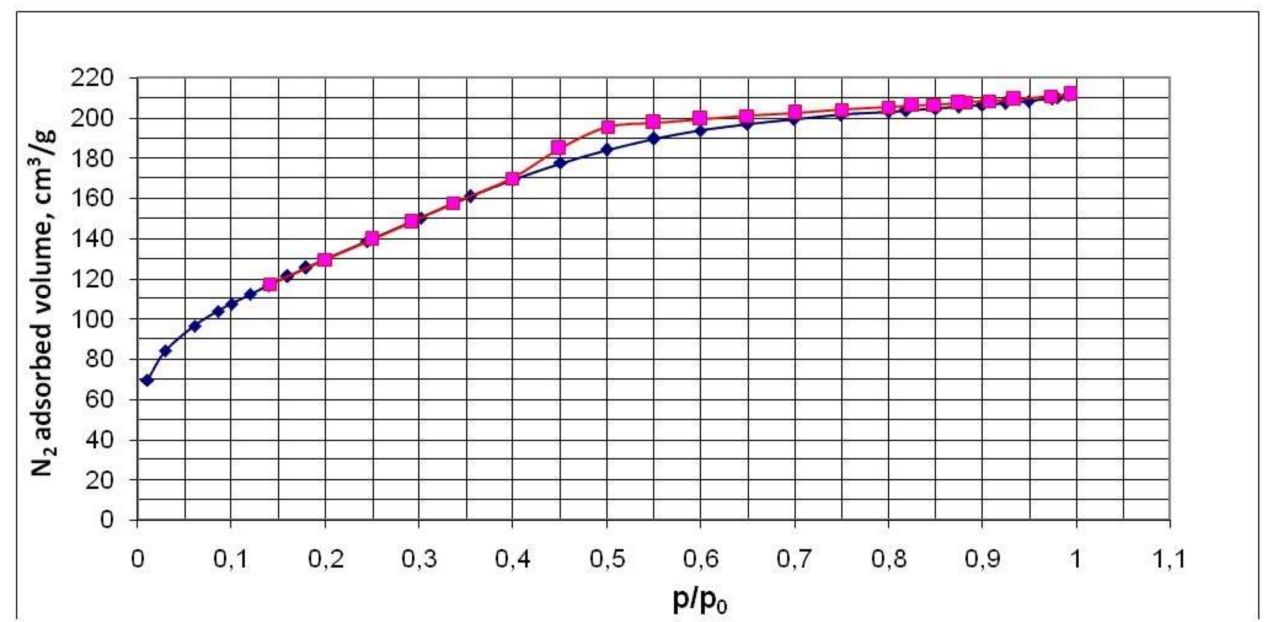

(a)

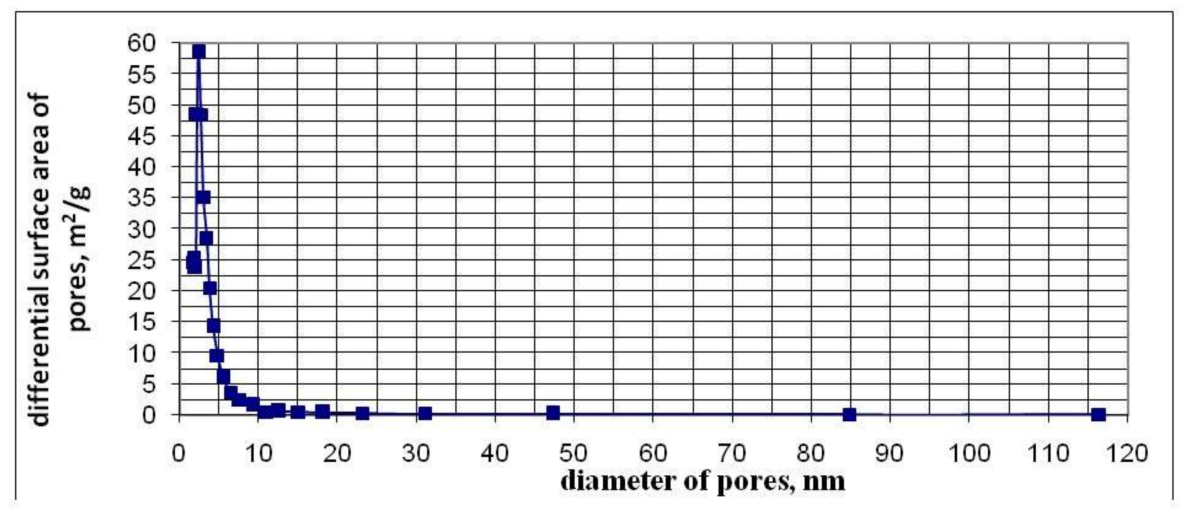

(b)

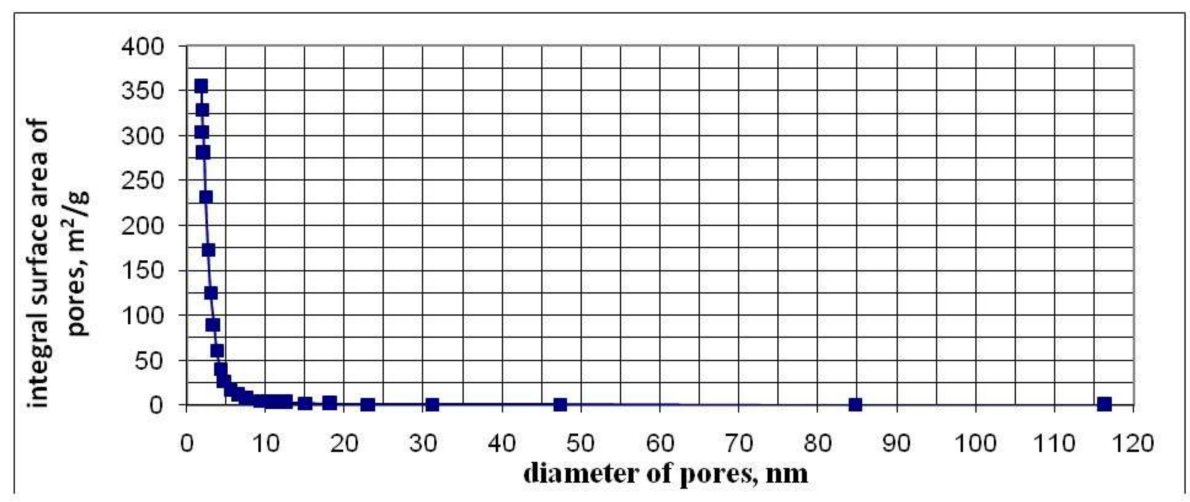

(c)

Figure 11. Cont. 


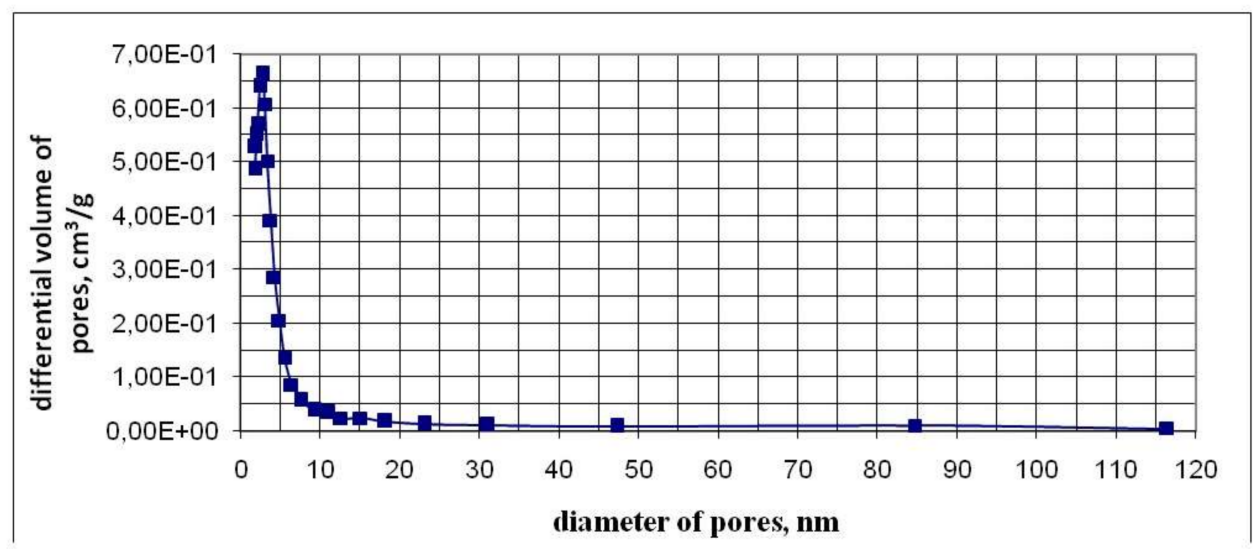

(d)

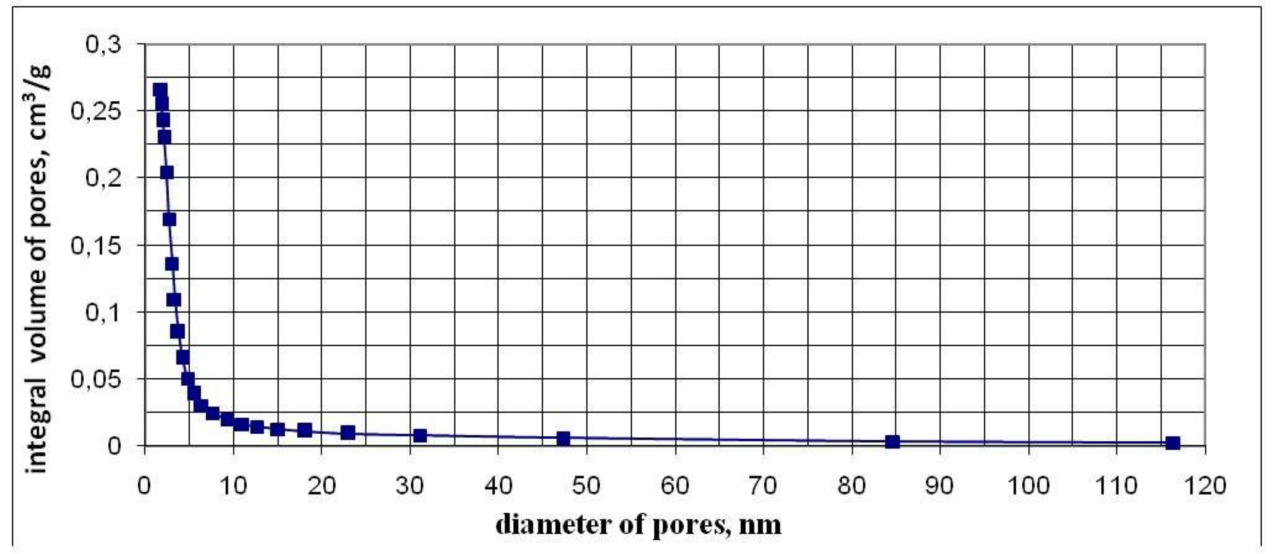

(e)

Figure 11. Pore characteristics of the UF-12-6 sample obtained by the low-temperature nitrogen adsorption method: (a) adsorption-desorption curves $\left(\mathrm{p} / \mathrm{p}_{0}\right.$-relative nitrogen pressure, $\mathrm{p}_{0}$-nitrogen saturation pressure at a temperature of $77 \mathrm{~K})$; (b) differential distribution of area over pore diameter; (c) integral distribution of the area along the pore diameter; (d) differential distribution of volume over pore diameter; (e) integral distribution of volume by pore diameter.

The ratio of the average pore diameter $d_{p}$ to the average surface particle diameter $d_{B E T}$ for most of the nanopowder samples ranged from 0.3 to 0.43 , to 0.5 (Table 3), which also testified to the high-volume density of the packing of $\mathrm{SiO}_{2}$ particles in the aggregates. The differential distributions of the pore area and volume over the diameters are rather narrow and are characterized by a relatively small width. The fraction of micropore area in the studied nanopowders is no more than $10 \%$ to $15 \%$, and the proportion of micropore volume is not more than $1 \%$ to $3 \%$ (Table 3).

The samples NM-200, 201, 204 of $\mathrm{SiO}_{2}$ nanopowders were produced by precipitation from precursor $\mathrm{Na}_{2} \mathrm{SiO}_{3}$ and the samples of pyrogenic $\mathrm{SiO}_{2}$ nanopowders were produced by the flame hydrolysis of $\mathrm{SiCl}_{4}$ [1]. Nitrogen sorption-desorption isotherms of precipitated samples NM-200, NM-201 and of pyrogenic $\mathrm{SiO}_{2}$ nanopowder NM-202 were another type then of hydrothermal nanosilica powdes (Figures 9-12). Pore characteristics of pyrogenic and precipitated $\mathrm{SiO}_{2}$ nanopowders established by BET-method are in Table 4. The form of the hysteresis loop of NM-200, 201, and 202 samples differs from the form of loop of hydrothermal samples, and the structure of $\mathrm{SiO}_{2}$ particles aggregates and agglomerates differs in precipitated and pyrogenic samples from the hydrothermal samples. 
Table 4. Pore characteristics of pyrogenic and precipitated $\mathrm{SiO}_{2}$ nanopowders [1] established by the BET(Brunauer-Emmett-Teller)-method.

\begin{tabular}{cccccc}
\hline Sample ID & $\rho_{\mathbf{p}}, \mathbf{g} / \mathbf{d m}^{3}$ & $\mathbf{S}_{\mathrm{BET}}, \mathbf{~ m}^{\mathbf{2}} \mathbf{g}$ & $\begin{array}{c}\text { Pore Volume, } \\
\mathbf{c m}^{\mathbf{3}} / \mathbf{g}\end{array}$ & $\begin{array}{c}\text { Area of } \\
\text { Micropores, } \mathbf{~}^{\mathbf{2}} / \mathbf{g}\end{array}$ & $\begin{array}{c}\text { Volume of } \\
\text { Micropores, } \mathbf{~ c m}^{\mathbf{3}} / \mathbf{g}\end{array}$ \\
\hline NM-200 & 120.0 & 189.1 & 0.79 & 30.0 & 0.01181 \\
\hline NM-201 & 280.0 & 140.4 & 0.581 & 23.1 & 0.00916 \\
\hline NM-202 & 130.0 & 204.1 & 0.513 & 8.26 & 0.00084 \\
\hline NM-203 & 30.0 & 203.9 & 0.499 & 5.3 & 0.0 \\
\hline NM-204 & 160.0 & 136.6 & 0.50 & 17.48 & 0.00666 \\
\hline
\end{tabular}

The specific pore volume $V_{p}=0.499-0.513 \mathrm{~cm}^{3} / \mathrm{g}$ of pyrogenic $\mathrm{SiO}_{2}$ nanopowder NM-202, 203 showed that the volume fraction $V_{s} / V_{\text {aggr }}$ of $\mathrm{SiO}_{2}$ particles in aggregates was about 0.5 . In the samples of precipitated nanopowders NM-200, 201, 204 with $V_{p}=0.79,0.581,0.50$ volume fraction was $V_{s} / V_{\text {aggr }}=0.364,0.438,0.475$. The volume fraction $V_{s} / V_{a g g}$ in the samples NM-(200-204) was lower than in the UF samples of hydrothermal nanopowders and indicated another structure of aggregates. The fraction of the area of the micropore and volume were the same as in UF samples.

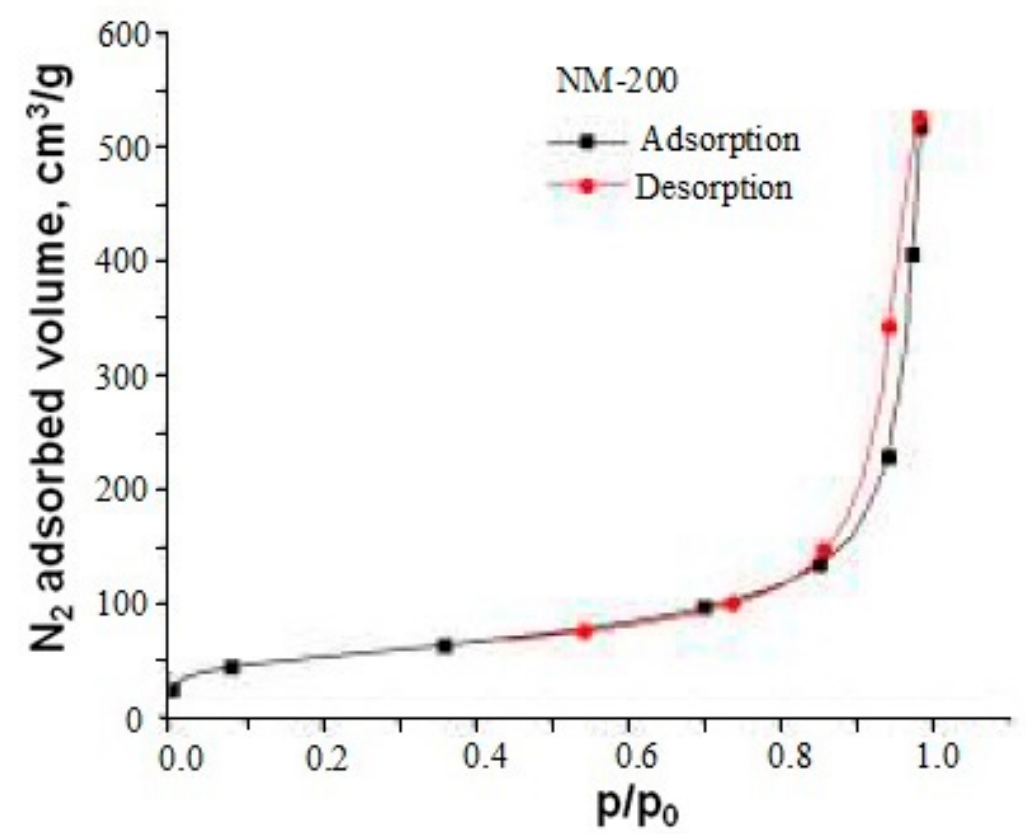

(a)

Figure 12. Cont. 


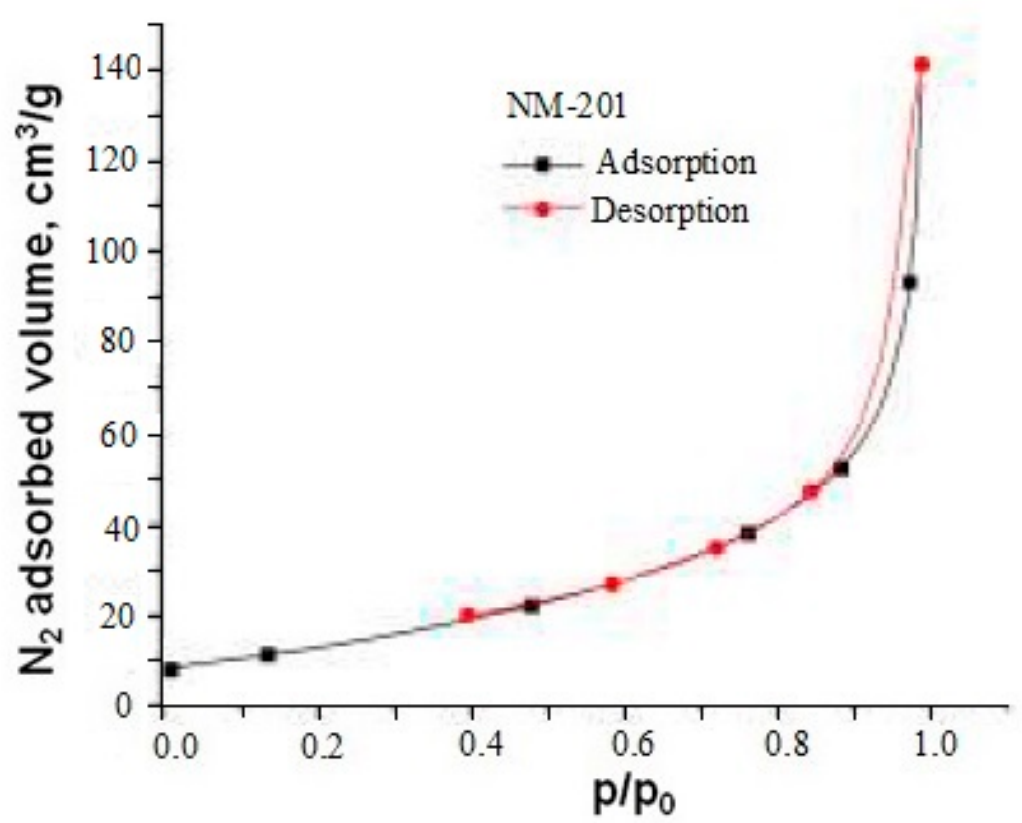

(b)

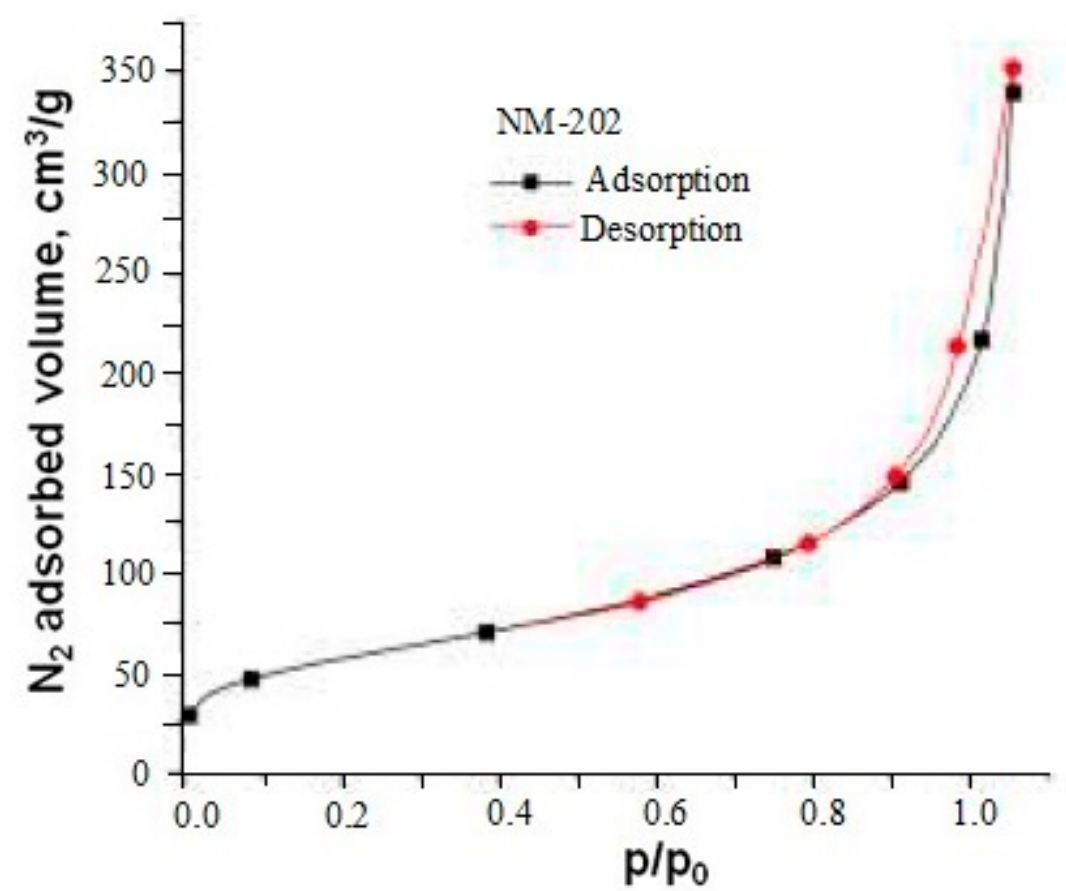

(c)

Figure 12. The curves of adsorption-desorption of precipitated NM-200, NM-201 and pyrogenic NM-202 samples of $\mathrm{SiO}_{2}$ nanopowders: (a) sample NM-200, (b) sample NM-201, (c) sample NM-202 [1].

\subsection{The XRD Data and Small Angle X-ray Scattering}

Samples of nanopowders had an amorphous structure without the presence of crystalline phases (Figure 13a). After calcination at $1200{ }^{\circ} \mathrm{C}$ for $2 \mathrm{~h}$, cristobalite peaks appeared in the diffractogram of the samples (Figure 13b). In the X-Ray data of all samples NM-200, 201, 204 precipitated from $\mathrm{Na}_{2} \mathrm{SiO}_{3}$ precursor the presence of $\mathrm{Na}_{3} \mathrm{SO}_{4}$ crystalline impurities at $2 \Theta=32,34$ degrees and crystalline impurities of Boehmite $(\gamma-\mathrm{AlO}(\mathrm{OH}))$ were observed [1]. In the pyrogenic samples NM-202 and 203, the presence of Boehmite was detected by XRD [1]. 


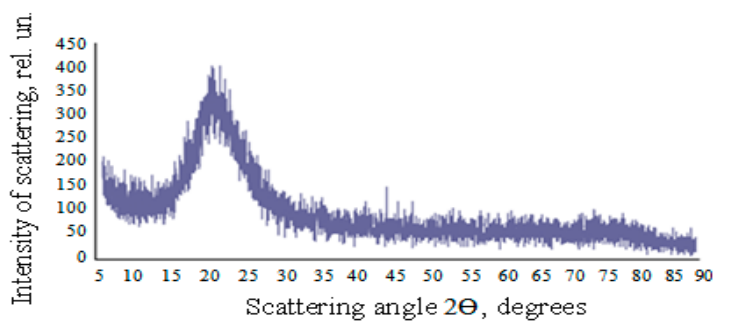

(a)

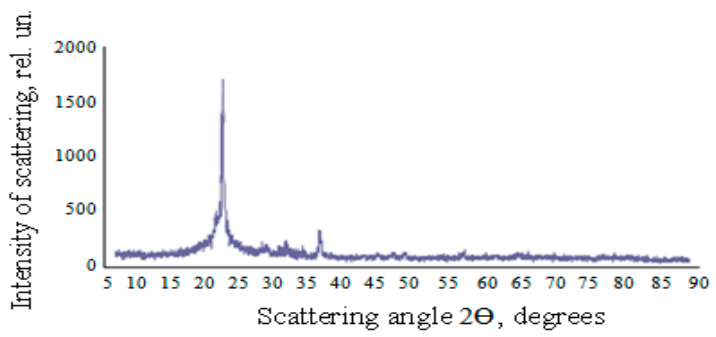

(b)

Figure 13. The XRD data of the nanopowder: (a) before calcination; (b) after calcination; $\Theta$ is the angle between the plane of the sample and the direction of radiation incidence. ARL X'TRA device (CuKa radiation, wavelength: $1.54 \AA$ ).

Samples of $\mathrm{SiO}_{2}$ nanopowders isolated from sols were studied by small angle X-ray scattering (SAXS) (Figure 14). The dependences of the intensity of the scattered electromagnetic radiation ISR (q) on the wave vector $q=4 \pi \times \sin (\Theta) / \lambda(\Theta$ is half the scattering angle and $\lambda$ is the X-ray wavelength) were obtained for five different samples of $\mathrm{SiO}_{2}$ nanopowders in logarithmic coordinates. Sample 1: nanopowder obtained by cryochemical vacuum sublimation of the sol with a $\mathrm{SiO}_{2}$ content of $100 \mathrm{~g} / \mathrm{dm}^{3}$ (precursor: hydrothermal solution). Samples 2 and 3: for nanopowders obtained by sol-gel and cryochemical vacuum sublimation of gels, the precursor is an aqueous solution of sodium silicate, the $\mathrm{SiO}_{2}$ content in the sol is $100 \mathrm{~g} / \mathrm{dm}^{3}$. Sample 4: for nanopowder obtained by sol-gel transition and cryochemical vacuum sublimation of the gel, the precursor is an hydrothermal solution, $\mathrm{SiO}_{2}$ content in the sol $100 \mathrm{~g} / \mathrm{dm}^{3}$. Sample 5: for nanopowder obtained by sol-gel transition and gel drying, the precursor is tetraethoxysilane.

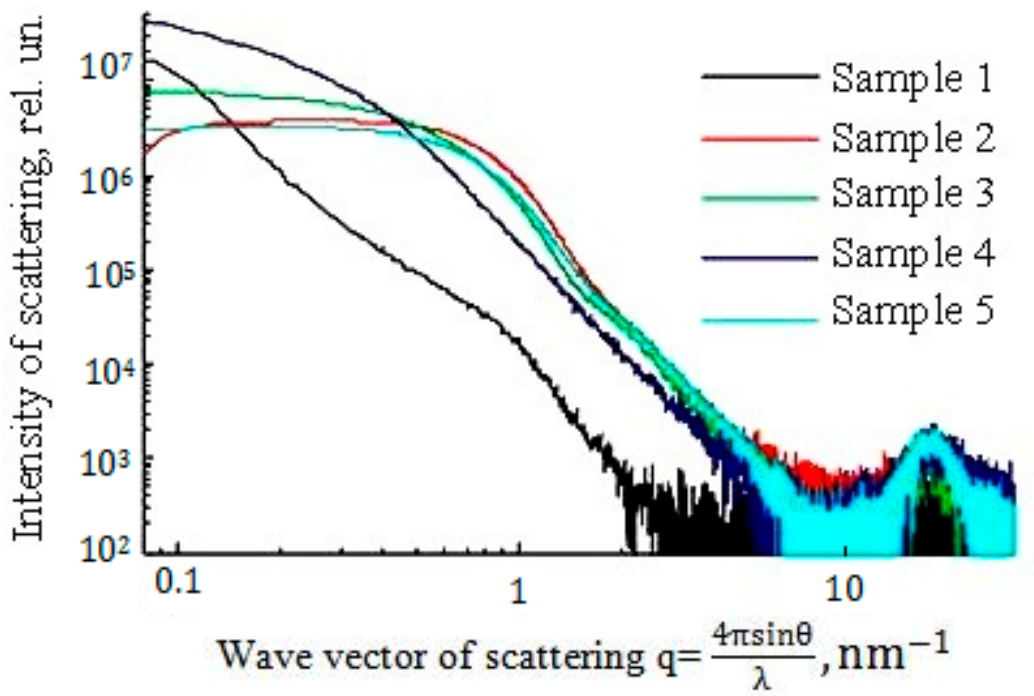

Figure 14. The results of measurements by the method of small-angle X-ray scattering.

According to Figure 14, only for sample 1 graph $\log I_{S R}(q)-\log (q)$ in the range $q=0.21$ to $0 \mathrm{~nm}^{-1}$ was close to linear, which indicates the mode of scattering by fractal agglomerates [51-57]:

$$
\mathrm{I}_{\mathrm{SR}} \sim \mathrm{q}^{-\mathrm{Df}}
$$

where $D_{f}$ is the fractal dimension. According to the slope of the dependence $\log I_{S R}(q)-\log (q)$, the dimension $D_{f}$ for the nanopowder of sample 1 was 2.21 . In the range $q=1.0$ to $3.0 \mathrm{~nm}^{-1}$ for sample 1, the modulus of the slope of the $\log I_{S R}(q)-\log (q)$ dependence was 4.05, in the region $q=0.08$ to $0.2 \mathrm{~nm}^{-1}$, it was 3.97, which corresponds to Porod's scattering regime. For sample 1, approximation of the dependence $\log I_{S R}(q)$ by the Guinier's function is $I_{S R}(q)=\exp \left(-R_{g}{ }^{2} \times q^{2} / 3\right)$. Here, $R_{g}$ is the gyration 
radius, for the ranges $q=1.0$ to $3.0 \mathrm{~nm}^{-1}$ and $q=0.08$-to $0.2 \mathrm{~nm}^{-1}$, respectively, where the primary particle size is $2 R_{g 1}=4.92 \mathrm{~nm}$ and the gyration radius of agglomerates is $2 R_{g 2}=24.4 \mathrm{~nm}$. The relation between gyration radius $R_{g 2}$ and outer diameter of agglomerates outer diameter $D_{\text {agglom }}$ is $D_{\text {agglom }}=\left(\left(D_{f}\right.\right.$ $\left.+2) / D_{f}\right)^{0.5} \times 2 R_{g 2}=33.7 \mathrm{~nm}$. The number $N_{\text {agglom }}$ of primary $\mathrm{SiO}_{2}$ nanoparticles with a diameter of $2 R_{g 1}$, which are in the fractal agglomerate of size $D_{\text {agglom }}$, can estimated as $[54,55]$ :

$$
\mathrm{N}_{\text {agglom }}=\left(\mathrm{D}_{\text {agglom }} / 2 \times \mathrm{R}_{\mathrm{g} 1}\right)_{\mathrm{f}}^{\mathrm{D}_{\mathrm{f}}}=69.3 \sim 69-70 .
$$

The average volume fraction of $\mathrm{SiO}_{2}$ primary particles in agglomerate is $\left(D_{\text {agglom }} / 2 \times R_{g 1}\right)_{f}^{D_{f}^{-3}}=0.218$.

For sample 4, the scattering mode on $I_{S R} \sim q^{-D}$ fractals was realized in the range $\mathrm{q}=0.2$ to $0.5 \mathrm{~nm}^{-1}$. The fractal dimension, determined by the slope of the dependence $\log I_{S R}(q)-\log (q)$, is $D_{f}=2.33$.

Nanopowders obtained by cryochemical vacuum sublimation of sols based on a hydrothermal solution were characterized by a fractal dimension in the range $D_{f}=2.04$ to 2.21. Sodium silicate and tetraethoxysilane nanopowders were characterized by $D_{f}=2.2$ to 2.3 .

Sample NM-202 of pyrogenic $\mathrm{SiO}_{2}$ powder obtained by the flame hydrolysis of $\mathrm{SiCl}_{4}$ was characterized by SAXS, TEM, DLS and BET methods in [1]: $D_{f}=2.5,2 \times R_{g 1}=16 \mathrm{~nm}, 2 \times R_{g 2}=$ $100 \mathrm{~nm}, N_{\text {agglom }}=200$. Two samples, NM-200 and NM-201, were produced by precipitation from the precursor solution of $\mathrm{Na}_{2} \mathrm{SiO}_{3}$ were characterized by parameters: $\mathrm{NM}-200-D_{f}=2.45,2 \times R_{g 1}=18 \mathrm{~nm}$, $2 \times R_{g 2}=440 \mathrm{~nm}, N_{\text {agglom }}=3500 ; \mathrm{M}-201-D_{f}=2.45,2 \times R_{g 1}=20 \mathrm{~nm}, 2 \times R_{g 2}=80 \mathrm{~nm}, N_{\text {agglom }}=457$. Fractal dimension of the hydrothermal nanopowders samples was lower than of the precipitated and pyrogenic samples $[1,52,54,57,58]$. Physicochemical and biophysicochemical interactions of nanoparticles with cells are in strong dependence from fractal dimension $D_{f}$ and parameters of the structure of agglomerates $2 \times R_{g 1}, D_{\text {agglom }}, N_{\text {agglom }}$, as from particles shape, surface electric charge and morphology [59-64].

\subsection{The Limits of the Content of Impurity Components in Nanopowders}

Table 5 shows the concentrations of impurity components in the silica nanopowder obtained by cryochemical vacuum sublimation of the sol at a $\mathrm{SiO}_{2}$ content of $500 \mathrm{~g} / \mathrm{dm}^{3}$ in the sol. The total content of impurities with respect to $\mathrm{SiO}_{2}$ does not exceed $0.3 \mathrm{wt}$ \%.

Table 5. The concentration of the chemical components of silica nanopowder (X-ray fluorescence spectrometer "S4 PIONEER").

\begin{tabular}{cc}
\hline Oxides & Concentration, wt. $\%$ \\
\hline $\mathrm{SiO}_{2}$ & 99.7 \\
\hline $\mathrm{TiO}_{2}$ & 0.00 \\
\hline $\mathrm{Al}_{2} \mathrm{O}_{3}$ & 0.173 \\
\hline $\mathrm{FeO}$ & 0.00 \\
\hline $\mathrm{Cr}_{2} \mathrm{O}_{3}$ & 0.00 \\
\hline $\mathrm{MgO}$ & 0.00 \\
\hline $\mathrm{CaO}$ & 0.034 \\
\hline $\mathrm{Na}{ }_{2} \mathrm{O}$ & 0.034 \\
\hline $\mathrm{K}_{2} \mathrm{O}$ & 0.069 \\
\hline $\mathrm{MnO}$ & 0.00 \\
\hline $\mathrm{NiO}$ & 0.00 \\
\hline $\mathrm{ZnO}$ & 0.00 \\
\hline $\mathrm{Total}$ & 100.0 \\
\hline
\end{tabular}




\subsection{Evaluation of the Density of Surface Silanol Groups of Si-OH}

Table 6 shows the dependence of the mass of the nanopowder sample (wt.\%) on temperature, according to thermogravimetric analysis.

Table 6. Dependence of the mass of the nanopowder sample (wt.\%) on temperature.

\begin{tabular}{cccccccccccc}
\hline $\mathbf{2 2 . 6}{ }^{\circ} \mathbf{C}$ & $\mathbf{1 0 0}{ }^{\circ} \mathbf{C}$ & $\mathbf{2 0 0}{ }^{\circ} \mathbf{C}$ & $\mathbf{3 0 0}{ }^{\circ} \mathbf{C}$ & $\mathbf{4 0 0}{ }^{\circ} \mathbf{C}$ & $\mathbf{5 0 0}{ }^{\circ} \mathbf{C}$ & $\mathbf{6 0 0}^{\circ} \mathbf{C}$ & $\mathbf{7 0 0}^{\circ} \mathbf{C}$ & $\mathbf{8 0 0}{ }^{\circ} \mathbf{C}$ & $\mathbf{9 0 0}{ }^{\circ} \mathbf{C}$ & $\mathbf{1 0 0 0}{ }^{\circ} \mathbf{C}$ & $\mathbf{1 1 0 0}^{\circ} \mathbf{C}$ \\
\hline $100 \%$ & $94.65 \%$ & $92.81 \%$ & $92.10 \%$ & $91.30 \%$ & $90.58 \%$ & $90.09 \%$ & $89.76 \%$ & $89.49 \%$ & $89.27 \%$ & $89.09 \%$ & $88.61 \%$ \\
\hline
\end{tabular}

Taking into account the specific surface area of silica $\mathrm{S}_{\mathrm{BET}}\left(\mathrm{m}^{2} / \mathrm{g}\right)$ and the mass loss $\Delta \mathrm{mH}_{2} \mathrm{O}$ (wt.\%) due to the removal of water and $\mathrm{OH}$-groups during thermogravimetric analysis, one can find the total concentration $\delta_{\mathrm{OH}}\left(\mathrm{OH} / \mathrm{nm}^{2}\right)$ of all silanol groups. These groups are located both on the surface and in the volume of silica conventionally assigned to the specific surface of the nanopowder sample [65]:

$$
\delta_{\mathrm{OH}}=\left(\Delta \mathrm{m}_{\mathrm{H} 2 \mathrm{O}} 2 \times 6.02 \times 10^{3}\right) /\left(18 \times \mathrm{S}_{\mathrm{BET}}\right) .
$$

Having taken $\mathrm{S}_{\mathrm{BET}}=300 \mathrm{~m}^{2} / \mathrm{g}$ for the sample, the final temperature at which all silanol groups are completely removed is equal to $1000{ }^{\circ} \mathrm{C}$, and taking into account the data in Table 5, the values of the total $\delta_{\mathrm{OH}}$ (on the surface and inside the volume) were obtained. These values conventionally calculated per unit surface area of the sample for different temperatures (Table 7).

Table 7. Distribution of $\mathrm{OH}$-groups between surface and volume for hydrothermal silica sample.

\begin{tabular}{ccccccccc}
\hline$T,{ }^{\circ} \mathrm{C}$ & 200 & 300 & 400 & 500 & 600 & 700 & 800 & 900 \\
\hline$\delta_{\mathrm{OH}}, \mathbf{O H} / \mathbf{n m}^{2}$ & 8.29 & 6.71 & 4.92 & 3.33 & 2.23 & 1.49 & 0.89 & 0.40 \\
\hline$\alpha_{\mathrm{OH}}, \mathbf{O H} / \mathbf{n m}^{2}$ & 4.90 & 3.56 & 2.33 & 1.84 & 1.52 & 1.30 & 0.70 & 0.40 \\
\hline$\gamma_{\mathrm{OH}}, \mathbf{O H} / \mathbf{n m}^{2}$ & 3.39 & 3.15 & 2.59 & 1.49 & 0.71 & 0.19 & 0.19 & 0.0 \\
\hline
\end{tabular}

Note. Symbol $T,{ }^{\circ} \mathrm{C}$-temperature of sample pretreatment in vacuum. $\delta_{\mathrm{OH}}$ is the total water loss obtained by thermogravimetric analysis when the sample was calcined to high temperatures and expressed as the number of $\mathrm{OH}$ - groups, referred to the surface unit of $\mathrm{SiO}_{2} . \alpha_{\mathrm{OH}}$ is the averaged total true concentration of silanols on the $\mathrm{SiO}_{2}$ surface depending on the pretreatment temperature obtained by Zhuravlev according to the method of deutero-exchange [66]. $\gamma_{\mathrm{OH}}$ is the content of internal silanols per unit surface area of $\mathrm{SiO}_{2}$, obtained as the difference between the corresponding $\delta_{\mathrm{OH}}$ and $\alpha_{\mathrm{OH}}$ values at the same fixed temperature (this value is also formally expressed as the number of $\mathrm{OH}$ groups per unit surface area of $\left.\mathrm{SiO}_{2}\left(\gamma_{\mathrm{OH}}, \mathrm{OH} / \mathrm{nm}^{2}\right)\right)$.

\subsection{Experiments with Compacted $\mathrm{SiO}_{2}$ Nanopowders}

Samples of $\mathrm{SiO}_{2}$ nanopowder were compacted on a hydraulic press at pressures of 1000 to 2000 $\mathrm{MPa}$ for 2 to $24 \mathrm{~h}$; then, after hardening, they calcined at temperatures of $700,800,1000$, and $1100{ }^{\circ} \mathrm{C}$ for 2 to $4 \mathrm{~h}$. After compaction and calcination, the mechanical characteristics of solid samples were determined using the Shimadzu complex with registration of the force-strain curves (Figures 15 and 16, Table 8). Table 8 shows the values of compressive strength in the range 135-337 MPa. This indicates a high specific surface and high surface energy of $\mathrm{SiO}_{2}$ nanoparticles. 


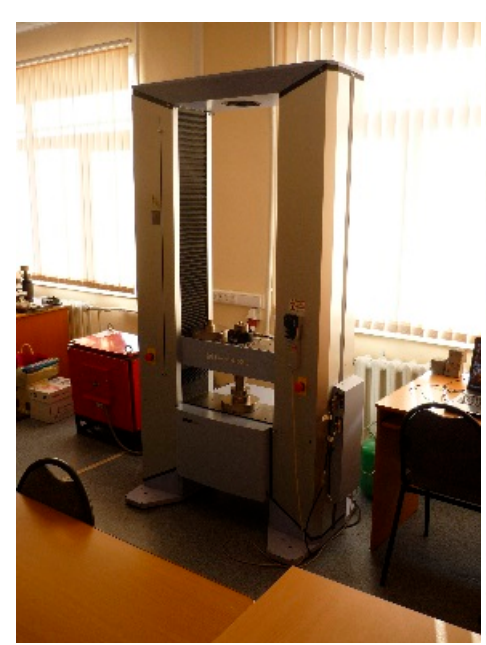

(a)

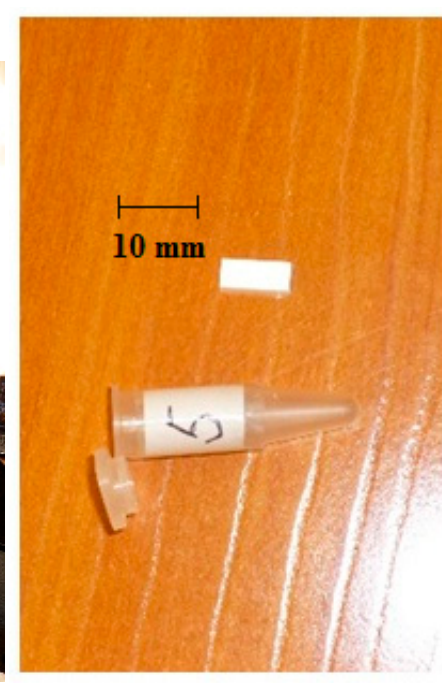

(b)

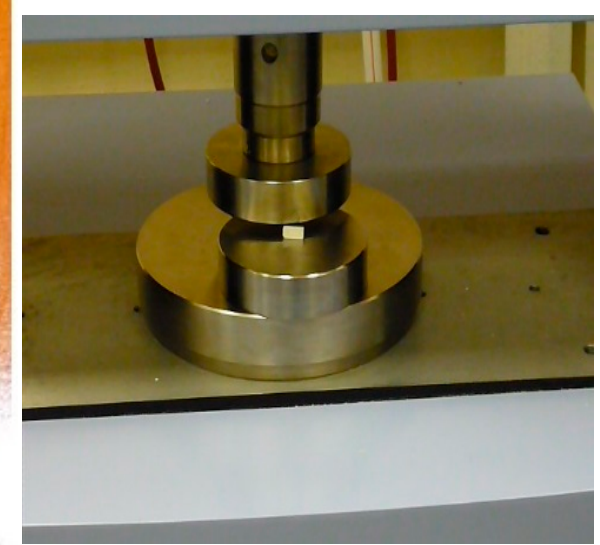

(c)

Figure 15. Strength tests of samples of compacted $\mathrm{SiO}_{2}$ nanopowder: (a) Shimadzu tester; (b) sample of compacted nanopowder; (c) sample before test.

Table 8. Characteristics of compacted $\mathrm{SiO}_{2}$ nanopowder samples during compressive strength tests.

\begin{tabular}{cccccccccc}
\hline $\begin{array}{c}\text { Sample } \\
\text { ID }\end{array}$ & $\begin{array}{c}\text { Speed, } \\
\mathbf{m m} / \mathbf{m i n}\end{array}$ & Shape & $\begin{array}{c}\text { Dimensions } \\
\text { (Thickness } \times \\
\text { Width } \times \\
\text { Height), } \mathbf{m m}\end{array}$ & $\begin{array}{c}\text { Maximum } \\
\text { Force, } \mathbf{N}\end{array}$ & $\begin{array}{c}\text { Maximum } \\
\text { Strain, } \\
\mathbf{N} / \mathbf{m m}^{2}\end{array}$ & $\begin{array}{c}\text { Amplitude } \\
\text { of the Stroke, } \\
\mathbf{m m}\end{array}$ & $\begin{array}{c}\text { Maximum } \\
\text { Elongation, } \\
\%\end{array}$ & $\begin{array}{c}\text { Maximum } \\
\text { Elongation, } \\
\text { mm }\end{array}$ & $\begin{array}{c}\text { Maximum } \\
\text { Time, s }\end{array}$ \\
\hline 1 & 1 & plane & $4.9 \times 11.9 \times 3.3$ & 11735.4 & 201.259 & 0.42831 & 12.9792 & 0.42831 & 25.7 \\
\hline 2 & 1 & plane & $4.9 \times 11.9 \times 3.6$ & 17145.4 & 294.040 & 0.65710 & 18.2529 & 0.65710 & 39.46 \\
\hline 3 & 1 & plane & $5.5 \times 13.5 \times 3.1$ & 10032.2 & 135.114 & 1.80619 & 58.2641 & 1.80619 & 108.370 \\
\hline 4 & 1 & plane & $5.1 \times 12.0 \times 3.5$ & 18897.6 & 308.784 & 1.81967 & 51.9905 & 1.81967 & 109.170 \\
\hline 5 & 1 & plane & $5.0 \times 11.9 \times 2.9$ & 20057.6 & 337.102 & 1.68196 & 57.9986 & 1.68196 & 100.950 \\
\hline
\end{tabular}

Sizes of the sample 5 (thickness $\times$ width $\times$ height), mm: $5.0 \times 11.9 \times 2.9$; sample density $1.7 \mathrm{~g} / \mathrm{cm}^{3}$; indentation speed $1 \mathrm{~mm} / \mathrm{min}$; maximum power $20057.6 \mathrm{~N}$; maximum strain $337.1 \mathrm{~N} / \mathrm{mm}^{2}$; amplitude of the stroke, $1.681 \mathrm{~mm}$; maximum elongation, $1.681 \mathrm{~mm}$; maximum deformation $57.88 \%$; maximum time 100.95 s.

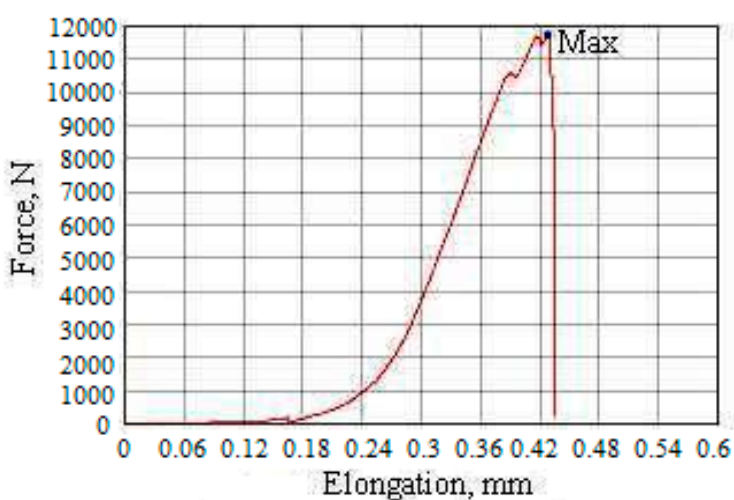

(a)

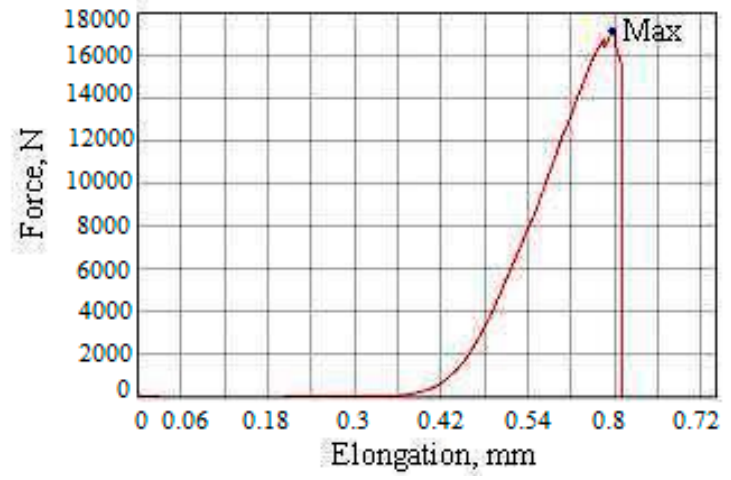

(b)

Figure 16. Cont. 


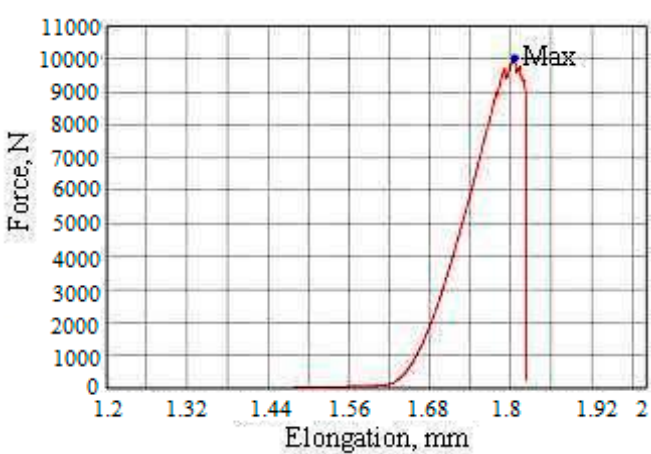

(c)

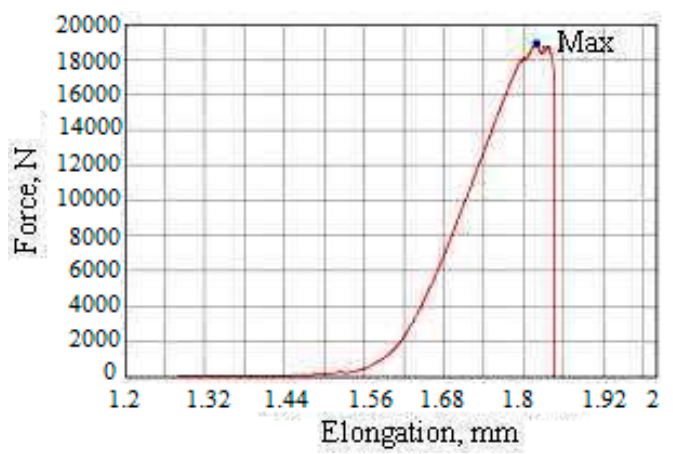

(d)

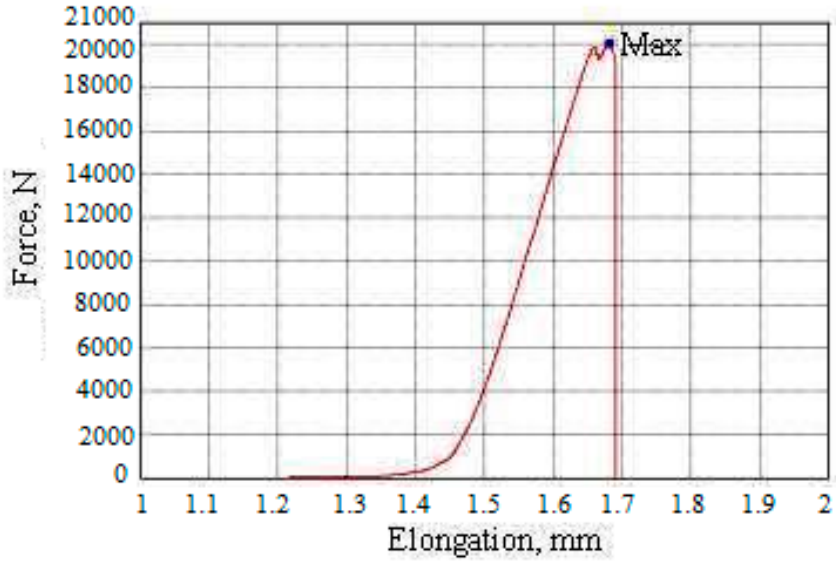

(e)

Figure 16. Curve force and elongation: (a) Sample 1; (b) Sample 2; (c) Sample 3; (d) Sample 4; (e) Sample 5 .

\section{Prospects for Research and Applications of Hydrothermal Nanopowders $\mathrm{SiO}_{2}$}

Further studies of the characteristics and possible applications of hydrothermal $\mathrm{SiO}_{2}$ nanopowders can be continued in the following areas:

- production of silicates of metals [67-69];

- receiving glasses;

- obtaining silicon carbide SiC;

- formation of ceramic forms based on $\mathrm{SiO}_{2}$ nanopowders;

- obtaining heat insulators;

- determination of the sorption capacity of nanopowders and obtaining sorbents for water purification and sorbents for gas chromatography;

- studies of the possibility of using nanopowders as catalyst supports.

Using $\mathrm{SiO}_{2}$ nanoparticles, which have a high and chemically active surface, one can purposefully influence [68-79]:

- the kinetics of hydration of the basic cement minerals $\mathrm{C}_{3} \mathrm{~S}, \mathrm{C}_{2} \mathrm{~S}, \mathrm{C}_{3} \mathrm{~A}, \mathrm{C}_{4} \mathrm{AF}$ and increasing the rate of CSH gel formation up to $20 \%$ and polymerisation $[68,69,77,78]$;

- reducing the size and shape of the particles of the gel of the hydrates of calcium silicate C-S-H, increasing the density of their volume packaging;

- reducing content of $\mathrm{Ca}(\mathrm{OH})_{2}$ up to $20 \%$ to $30 \%$ and, thus, increasing content of CSH gel in hardened concrete because of rapid kinetics of pozzolanic reaction of $\mathrm{SiO}_{2}$ nanoparticles with $\mathrm{Ca}(\mathrm{OH})_{2}[74,75]$; hydrothermal $\mathrm{SiO}_{2}$ nanoparticles with great specific surface area up to $500 \mathrm{~m}^{2} / \mathrm{g}$ and high chemical activity due the surface density of Si-OH groups up to $4.9 \mathrm{~nm}^{-2}$, which significantly accelerates the kinetics of pozzolanic reaction $[68,77,78]$; 
- increase the volume fraction of C-S-H gel phases with greater elasticity and hardness, $\mathrm{Ca} / \mathrm{Si}$ relation due to modification of nanostructure of hardened concrete, and, as a result, increase the compressive and bending strength of concrete, reduce pore volume, increase water resistance, frost resistance, chemical resistance, and, as a result, the durability of concrete.

Nanosilica obtained based on a hydrothermal solution is applicable as an effective nanomodifier of concrete and is used [77-79]:

(1) to accelerate hardening;

(2) increasing the compressive strength of concrete at the early age up to $120 \%$ and about $40 \%$ in the age of 28 days; increasing of the concrete's compressive strength with additive of hydrothermal nanosilica was $10 \%$ higher than with additive of colloid nanosilica based on $\mathrm{Na}_{2} \mathrm{SiO}_{3}$ precursor [72];

(3) reduction of Portland cement consumption up to $30 \%$.

A sufficiently developed application of hydrothermal $\mathrm{SiO}_{2}$ nanoparticles is the intensification of photosynthesis in chloroplasts of plant cells due to the photoluminescent radiation of $\mathrm{SiO}_{2}$ nanoparticles. $\mathrm{SiO}_{2}$ nanoparticles due their optical properties can absorb solar radiation in ultraviolet region with a wave-length of 200 to $360 \mathrm{~nm}$ and emit of luminescent radiation in visible region with a wave length of 400 to $500 \mathrm{~nm}$, in which the efficiency to absorb radiation by photosynthetic pigments and carotenoids is high [80-82]. An increase in the proportion of photosynthetic pigments of chlorophylls a $(62 \%)$ and $\mathrm{b}(79.3 \%)$ [82-84], as a result, an increase in the growth rate, biochemical and biometric indicators at all stages of plant growth and development, a significant increase crop yields of agricultural plants from $9 \%$ to $60 \%$ [82-85], increase of contents of carotenoids- $14.5 \%, \mathrm{~B}_{2}-130 \%, \mathrm{~B}_{5}-60 \%, \mathrm{~B}_{6}-230 \%$, $\mathrm{B}_{9}-230 \%$ and $\mathrm{C}-14.4 \%$ vitamins [82-84] and rising biological activity of raw plant's mass with respect to cultures of Daphnia magna-352\% and Paramecium caudatum-90.5\% [82-86]. Hydrothermal $\mathrm{SiO}_{2}$ nanoparticles have great inhibition ability on microflora (Leveilluia taurica, Ocidiopsis sicula) [87].

Hydrothermal nanosilica used as a feed additive that increases the productivity of farm animals ( $8 \%$ to $10 \%)$, rate of mass growth $(10 \%$ to $40 \%)$, strength of the bone $(17 \%)$, blood characteristics $(\mathrm{Ca} / \mathrm{P}$ relation) and immunity (25\% rising of the proportion of big forms of lymphocytes) [88-91].

Non-toxic [86-91] hydrothermal $\mathrm{SiO}_{2}$ nanopowders can be the basis for the creation of medical preparations:

- enterosorbents,

- drugs that improve the structure of bone, strength and plasticity of the articular-bone tissue and reduce Ca leaking.

\section{Conclusions}

1. A technological route proposed that allows one to obtain amorphous $\mathrm{SiO}_{2}$ nanopowders based on a hydrothermal solution. The scheme includes the OSA polycondensation processes, ultrafiltration membrane separation, and cryochemical vacuum sublimation. The route allows to regulate parameters of the structure of the powder: the pour density, the diameters of the particle, specific surface area, diameters, pore area and volume, volume fraction of spherical particles in aggregates and agglomerates, sizes of agglomerates and number of particles in agglomerates, and fractal dimension. The parameters of the structure of hydrothermal nanosilica powders $\left(\rho_{p}, d_{B E T}, S_{B E T}, V_{p}, V_{s} / V_{\text {aggr }}, 2 \times R_{g 1}, D_{\text {agglom }}, N_{\text {agglom }}\right.$, $D_{f}$ ) differs from precipitated and pyrogenic samples. The structure parameters determine physical and chemical activity and applications of nanopowders. The interactions between $\mathrm{SiO}_{2}$ nanoparticles, surface properties, parameters of double electric layer and stability of $\mathrm{SiO}_{2}$ nanoparticles differs in hydrothermal sols and nanopowders from interactions in sols produced from $\mathrm{Na}_{2} \mathrm{SiO}_{3}$ solutions or in precipited and pirogenic $\mathrm{SiO}_{2}$ nanopowders. The difference in interactions of $\mathrm{SiO}_{2}$ nanoparticles arised from the ion concentrations, ionic strength of hydrothermal solution and kinetics of OSA's polycondencation. The difference in nanoparticles interactions leads to the difference in structure parameters of nanopowders. The structure parameters determines physical and chemical activity of $\mathrm{SiO}_{2}$ nanopowders and it's applications. 
The interactions between $\mathrm{SiO}_{2}$ nanoparticles, surface properties, parameters of double electric layer and stability of $\mathrm{SiO}_{2}$ nanoparticles differs in hydrothermal sols and nanopowders from interactions in sols produced from $\mathrm{Na}_{2} \mathrm{SiO}_{3}$ solutions or in precipited and pirogenic $\mathrm{SiO}_{2}$ nanopowders. The difference in interactions of $\mathrm{SiO}_{2}$ nanoparticles arised from the ion concentractions, ionic strength of hydrothermal solution and kinetics of OSA's polycondencation. The difference in nanoparticles interactions leads to the difference in structure parameters of nanopowders. The structure parameters determines physical and chemical activity of $\mathrm{SiO}_{2}$ nanopowders and it's applications.

2. The values of the average particle diameter of $\mathrm{SiO}_{2}$ in sols, according to the data of dynamic light scattering, ranged from 5 to $100 \mathrm{~nm}$. The average particle diameter of $\mathrm{SiO}_{2}$ in powders, according to tunnel electron microscopy and the BET method, was in the same range of 5 to $100 \mathrm{~nm}$.

3. The pour density of nanopowders $\rho_{p}$ depended on the content of $\left[\mathrm{SiO}_{2}\right]$ in the sol and, therefore, on the concentration of particles and the average distance between them. When the content of $\left[\mathrm{SiO}_{2}\right]$ in sols ranged from 2.4 to $90 \mathrm{~g} / \mathrm{dm}^{3}$, the pour density was higher than $\left[\mathrm{SiO}_{2}\right]$, respectively $\mathrm{SiO}_{2}$ particles came together after sublimation of water molecules. At a content of $\left[\mathrm{SiO}_{2}\right]$ above $90 \mathrm{~g} / \mathrm{dm}^{3}$, the pour density was lower than $\left[\mathrm{SiO}_{2}\right]$ and the average distance between $\mathrm{SiO}_{2}$ particles, respectively, increased. In the range of $\left[\mathrm{SiO}_{2}\right]$ contents in sols from 100 to $520 \mathrm{~g} / \mathrm{dm}^{3}$, the $\rho_{p}\left(\left[\mathrm{SiO}_{2}\right]\right)$ dependence was close to linear.

4. By lowering the temperature of the hydrothermal solution at the OSA polycondensation stage from 90 to $20^{\circ} \mathrm{C}$, we achieved a decrease in the size of $\mathrm{SiO}_{2}$ particles and, accordingly, an increase in their specific surface to $500 \mathrm{~m}^{2 /} \mathrm{g}$ and a decrease in pore diameter from 15 to $2.7 \mathrm{~nm}$. The specific pore volume was in the range of 0.20 to $0.30 \mathrm{~cm}^{3} / \mathrm{g}$ and varied little depending on the specific surface area and density of nanopowders. Spherical particles of $\mathrm{SiO}_{2}$ in nanopowders form aggregates with a high-volume fraction of 0.7 to 0.6 . The density of matter in aggregates, $1.32-1.54 \mathrm{~g} / \mathrm{cm}^{3}$, was significantly higher than the density of nanopowders, which was $0.02-0.274 \mathrm{~g} / \mathrm{cm}^{3}$. The ratio of the average pore diameter $d_{p}$ to the average surface particle diameter $d_{B E T}$ from $0.3-0.43$ to 0.5 also indicated a high-volume fraction of the packing of $\mathrm{SiO}_{2}$ particles in the aggregates. According to the SAXS data, aggregates of $\mathrm{SiO}_{2}$ nanoparticles form agglomerates with a fractal dimension of 2.04-2.21.

5. The content of impurity components in nanopowders can be brought up to $0.3 \mathrm{wt}$. $\%$ due to ultrafiltration membrane separation of $\mathrm{SiO}_{2}$ nanoparticles and ions of dissolved salts, an increase in the $\mathrm{SiO}_{2}$ content in the sol, and an increase in the ratio $\mathrm{m}_{\mathrm{s}}=\left[\mathrm{SiO}_{2}\right] / \mathrm{TDS}$ to 300 and higher.

6. Tests of compacted $\mathrm{SiO}_{2}$ nanopowders showed values of compressive strength in the range 135-337 MPa. This indicates a high specific surface area and high surface energy of $\mathrm{SiO}_{2}$ nanoparticles.

7. Nanopowders obtained by the proposed technology have prospects for the use in the production of glass, silicon carbide, ceramics, concrete nanomodifiers, sorbents, plant growth stimulants, feed additives for agricultural animals, and medicines.

Author Contributions: Technological route for nanosilica production from hydrothermal solution by using the processes of OSA polycondensation, ultrafiltration membrane concentration and vacuum sublimation proposed by V.P. and R.F. made significant contribution in the plan of research work on nanosilica characteristics, in evaluation of experimental results and analysed the ways of possible applications of hydrothermal nanosilica in chemical industry, building materials, agriculture and medicine. Construction of membrane's and vacuum sublimation's plants, experiments on $\mathrm{SiO}_{2}$ nanopowders production under different conditions were done by D.G. All the authors took an active part in manuscript's preparation and discussion. All authors have read and agreed to the published version of the manuscript.

Funding: This research received no external funding.

Conflicts of Interest: The authors declare that they have no conflict of interests.

\section{References}

1. Synthetic Amorphous Silicon Dioxide (NM-200, NM-201, NM-202, NM-203, NM-204): Characterisation and Physico-Chemical Properties. JRC Repository: NM-series of Representative Manufactured Nanomaterials. Joint Research Centre: Ispra, Italy. Available online: http:www.jrc.ec.europa.eu (accessed on 27 March 2020). 
2. Smith, D.M.; Scherer, G.W.; Anderson, J.M. Shrinkage during drying of silica gel. Non-Cryst. Solids 1995, 188, 191-206. [CrossRef]

3. Ru, Y.; Guangyan, Z.; Min, L.; Nan, J. Obtaining and properties of powdered $\mathrm{SiO}_{2}$ in the form of nanoparticles prepared by drying under supercritical conditions. Chin. Ceram. Soc. 2005, 33, 281-286.

4. Titulaer, M.K.; Jansen JB, H.; Geus, J.W. Fluid composition on silica gel aging. Non-Cryst. Solids 1994, 170, 11-20. [CrossRef]

5. Wijnen, P.W.; Beelen, T.P.; Rummens, K.P.; Saeijs, H.C.; De Haan, J.W.; Van De Ven, L.J.; A Van Santen, R. The molecular basis of aging of aqueous silica gel. J. Colloid Interface Sci. 1991, 145, 17-32. [CrossRef]

6. Rao, K.S.; El-Hami, K.; Kodaki, T.; Matsushige, K.; Makino, K. A novel method for synthesis of silica nanoparticles. J. Colloid Interface Sci. 2005, 289, 125-131. [CrossRef]

7. Costa, R.; Leite CA, P.; Galembeck, F. Size dependence of Stober silica nanoparticle microchemistry. Phys. Chem. B 2003, 107, 4747-4755. [CrossRef]

8. Grun, M.; Unger, K.K.; Matsumoto, A.; Tatsumi, K. Novel pathways for the preparation of mesoporous MCM-41 materials: Control of porosity and morphology. Micropor. Mesopor. Mater. 1999, 27, 207-216. [CrossRef]

9. Schumacher, K.; Grun, M.; Unger, K.K. Novel synthesis of spherical MCM-48. Micropor. Mesopor. Mater. 1999, 27, 201-206. [CrossRef]

10. Scholz, S.; Bare, S.R.; Kelly, S.D.; Lercher, J.A. Controlled one-step synthesis of hierarchically structured macroscopic silica spheres. Microporous Mesoporous Mater. 2011, 146, 18-27. [CrossRef]

11. Edler, K.; White, W. Further improvements in the long-range order of MCM-41 materials. Chem. Mater. 1997, 9, 1226-1233. [CrossRef]

12. Beck, J.S.; Vartuli, J.C.; Roth, W.J.; Leonowicz, M.E.; Kresge, C.T.; Schmitt, K.D.; Chu, C.T.W.; Olson, D.H.; Sheppard, E.W.; McCullen, S.B.; et al. A new family of mesoporous molecular sieves prepared with liquid crystal templates. J. Am. Chem. Soc. 1992, 114, 10834-10843. [CrossRef]

13. Ohkubo, T.; Ogura, T.; Sakai, H.; Abe, M. Synthesis of highly-ordered mesoporous silica particles using mixed cationic and anionic surfactants as templates. J. Colloid Interface Sci. 2007, 312, 42-46. [CrossRef] [PubMed]

14. Kim, J.H.; Yoon, S.B.; Kim, J.Y.; Chae, Y.B.; Yu, J.S. Synthhesis of monodisperse silica spheres with solid core and mesoporous shell: Morphological control of mesopores. Colloids Surf. A Physicochem. Eng. Asp. 2008, 313-314, 77-81. [CrossRef]

15. Firouzi, A.; Kumar, D.; Bull, L.; Besier, T.; Sieger, P.; Huo, Q.; Walker, S.; Zasadzinski, J.; Glinka, C.; Nicol, J.; et al. Cooperative organization of inorganic-surfactant and biomimetic assemblies. Science 1995, 267, 1138-1143. [CrossRef] [PubMed]

16. Suzuki, K.; Ikari, K.; Imai, H. Synthesis of Silica Nanoparticles Having a Well-Ordered Mesostructure Using a Double Surfactant System. J. Am. Chem. Soc. 2004, 126, 462-463. [CrossRef]

17. Grün, M.; Lauer, I.; Unger, K.K. The synthesis of micrometer- and submicrometer-size spheres of ordered mesoporous oxide MCM-41. Adv. Mater. 1997, 9, 254-257. [CrossRef]

18. Fu, X.; He, X.; Wang, Y. Facile preparation of silica hollow microspheres by precipitation-phase separation method. Colloids Surf. A Phys. Eng. Asp. 2011, 380, 241-249. [CrossRef]

19. Guo, W.; Luo, G.; Wang, Y. A new emulsion method to synthesize well-defined mesoporous particles. J. Colloid Interface Sci. 2004, 271, 400-406. [CrossRef]

20. Chen, F.; Song, F.; Li, Q. Mixed cationic-anionic templating route to Al-MCM-48. Micropor. Mesopor. Mater. 1999, 29, 305-310. [CrossRef]

21. Yang, H.; Vovk, G.; Coombs, N.; Sokolov, I.; Ozin, G.A. Synthesis of mesoporous silica spheres under quiescent aqueous acidic conditions. J. Mater. Chem. 1998, 8, 743-750. [CrossRef]

22. Guo, W.; Goh, D.-C.; Zhao, X.S. Synthesis of super-microporous organosilica microspheres through in situ self-assembly of nanoparticles. J. Mater. Chem. 2005, 15, 4112. [CrossRef]

23. Qi, L.; Ma, J.; Cheng, H.; Zhao, Z. Micrometer-Sized Mesoporous Silica Spheres Grown under Static Conditions. Chem. Mater. 1998, 10, 1623-1626. [CrossRef]

24. Zhao, D.; Sun, J.; Li, Q.; Stucky, G.D. Morphological Control of Highly Ordered Mesoporous Silica SBA-15. Chem. Mater. 2000, 12, 275-279. [CrossRef]

25. Nemoto, N.; Kuwahara, M. Dynamic light scattering of CTAB/sodium salicylate long threadlike micelles in the semidilute regime: Applicability of the dynamic scaling law. Langmuir 1993, 9, 419-423. [CrossRef] 
26. Ma, Y.; Qi, L.; Ma, J.; Wu, Y.; Liu, O.; Cheng, H. Large-pore mesoporous silica spheres: Synthesis and application in HPLC. Colloids Surf. A Phys. Eng. Asp. 2003, 229, 1-8. [CrossRef]

27. Eiden-Assmann, S.; Lindlar, B.; Maret, G. Synthesis and characterization of colloidal fluorescent mesoporous silica particles. J. Colloid Interface Sci. 2004, 271, 120-123. [CrossRef]

28. Allouche, J.; Dupin, J.-C.; Gonbeau, D. Generation of a mesoporous silica MSU shell onto solid core silica nanoparticles using a simple two-step sol-gel process. Chem. Commun. 2011, 47, 7476. [CrossRef]

29. Ho, J.; Zhu, W.; Wang, H.; Forde, G.M. Mesoporous silica spheres from colloids. J. Colloid Interface Sci. 2007, 308, 374-380. [CrossRef]

30. Yuying, P.U.; Jianzhang FA, N.G.; Feng PE, N.G.; Baojian, L.I.; Huang, L. Microemulsion synthesis of nanosized $\mathrm{SiO}_{2} / \mathrm{TiO}_{2}$ particles and their photocatalytic activity. Chin. J. Catal. 2007, 28, 251-256.

31. Yao, T.; Lin, Q.; Zhang, K.; Zhao, D.; Lv, H.; Zhang, J.; Yang, B. Preparation of $\mathrm{SiO}_{2}$ polystyrene-polypyrrole sandwich composites and hollow polypyrrole capsules with movable $\mathrm{SiO}_{2}$ spheres inside. J. Colloid Interface Sci. 2007, 315, 434-438. [CrossRef]

32. Yoldas, B.E. Monolithic glass formation by chemical polymerization. J. Mater. Sci. 1979, 14, $1843-1849$. [CrossRef]

33. Zhang, G.; Wang, Y.; Zhengyi, F.; Wang, H.; Wang, W.; Zhang, J.; Lee, S.W.; Niihara, K. Transparent mullite ceramic from single-phase gel by Spark Plasma Sintering. J. Eur. Ceram. Soc. 2009, 29, 2705-2711. [CrossRef]

34. Innocenzi, P.; Martucci, A.; Guglielmi, M.; Bearzotti, A.; Traversa, E.; Pivin, J.C. Mesoporous silica thin films for alcohol sensors. J. Eur. Ceram. Soc. 2001, 21, 1985-1988. [CrossRef]

35. Paul, J.; Romeis, S.; Mačković, M.; Marthala, V.R.R.; Herre, P.; Przybilla, T.; Hartmann, M.; Spiecker, E.; Schmidt, J.; Peukert, W. In situ cracking of silica beads in the SEM and TEM-Effect of particle size on structure-property correlations. Powder Technol. 2015, 270, 337-347. [CrossRef]

36. Bagheri, E.; Ansari, L.; Abnous, K.; Taghdisi, S.M.; Charbgoo, F.; Ramezani, M.; Alibolandi, M. Silica based hybrid materials for drug delivery and bioimaging. J. Control. Release 2018, 277, 57-76. [CrossRef] [PubMed]

37. Jang, J.; Yoon, H. Novel Fabrication of Size-Tunable Silica Nanotubes Using a ReverseMicroemulsion-Mediated Sol-Gel Method. Adv. Mater. 2004, 16, 799-802. [CrossRef]

38. Loganina, V.I.; Kislitsyna, S.N.; Mazhitov, Y.B.; Ivanovna, L.V.; Nikolaevna, K.S.; Bisengalievich, M.Y. Development of sol-silicate composition for decoration of building walls. Case Stud. Constr. Mater. 2018, 9. [CrossRef]

39. Kao, K.-C.; Lin, C.-H.; Chen, T.-Y.; Liu, Y.-H.; Mou, C.-Y. A General Method for Growing Large Area Mesoporous Silica Thin Films on Flat Substrates with Perpendicular Nanochannels. J. Am. Chem. Soc. 2015, 137, 3779-3782. [CrossRef]

40. Chęcmanowski, J.; Szczygieł, I.; Mazur, A.; Szczygiel, B. Protective properties of $\mathrm{SiO}_{2}$ with $\mathrm{SiO}_{2}$ and $\mathrm{Al}_{2} \mathrm{O}_{3}$ nanoparticles sol-gel coatings deposited on FeCrAl alloys. Ceram. Int. 2019, 45, 2811-2819. [CrossRef]

41. Matysiak, W.; Tański, T. Analysis of the morphology, structure and optical properties of $1 \mathrm{DSiO}_{2}$ nanostructures obtained with sol-gel and electrospinning methods. Appl. Surf. Sci. 2019, 489, 34-43. [CrossRef]

42. Liu, Y.; Cai, Z.; Sheng, L.; Ma, M.; Xu, Q. Influence of nanosilica on inner structure and performance of chitosan based films. Carbohydr. Polym. 2019, 212, 421-429. [CrossRef] [PubMed]

43. Sowntharya, L.; Gundakaram, R.C.; Raju, K.S.; Subasri, R. Effect of addition of surface modified nanosilica into silica-zirconia hybrid sol-gel matrix. Ceram. Int. 2013, 39, 4245-4252. [CrossRef]

44. Cai, Y.; Li, X.; Dong, J. Microstructure and mechanical properties of porous $\mathrm{Si}_{3} \mathrm{~N}_{4}-\mathrm{SiO}_{2}$ ceramics fabricated by a process combining carbothermal reduction and sol-gel infiltration-sintering. Mater. Sci. Eng. A 2014, 601, 111-115. [CrossRef]

45. Pronin, I.; Goryacheva, M.V. Principles of structure formation and synthesis models produced by the sol-gel method $\mathrm{SiO}_{2}-\mathrm{Me}_{\mathrm{x}} \mathrm{O}_{\mathrm{y}}$ nanocomposites. Surf. Coat. Technol. 2013, 235, 835-840. [CrossRef]

46. Asadi, Z.; Norouzbeigi, R. Synthesis of colloidal nanosilica from water glass powder as a low cost precursor. Ceram. Int. 2018, 44, 22692-22697. [CrossRef]

47. Bakar, R.A.; Yahya, R.; Gan, S.N. Production of High Purity Amorphous Silica from Rice Husk. Procedia Chem. 2016, 19, 189-195. [CrossRef]

48. Weres, O.; Yee, A.; Tsao, L. Kinetics of silica polymerization. J. Colloid Interface Sci. 1981, 84, $379-402$. [CrossRef]

49. Potapov, V.V.; Cerdan, A.A.; Kashutina, I.A. Numerical simulation of orthosilicic acid polycondensation and silica particles formation inhydrothermal solutions. Вулканология и сейсмология 2019, 4, 18-28. [CrossRef] 
50. Potapov, V.V.; Kamashev, D.V. Synthesis of precious opal in a hydrothermal solution. Glas. Phys. Chem. 2006, 32, 89-98. [CrossRef]

51. Beaucage, G. Small-Angle Scattering from Polymeric Mass Fractals of Arbitrary Mass-Fractal Dimension. J. Appl. Cryst. 1996, 29, 134-146. [CrossRef]

52. Kammler, H.K.; Beaucage, G.; Mueller, R.; Pratsinis, S.E. Structure of Flame-Made Silica Nanoparticles by Ultra-Small-Angle X-ray Scattering. Langmuir 2004, 20, 1915-1921. [CrossRef]

53. Kammler, H.K.; Beaucage, G.; Kohls, D.J.; Agashe, N.; Ilavsky, J. Monitoring simultaneously the growth of nanoparticles and aggregates by in situ ultra-smallangle X-ray scattering. Appl. Phys. 2005, 97, 9-11. [CrossRef]

54. Hyeon-Lee, J.; Beaucage, G.; Pratsinis, S.E.; Vemury, S. Fractal Analysis of Flame-Synthesized Nanostructured Silica and Titania Powders Using Small-Angle X-ray Scattering. Langmuir 1998, 14, 5751-5756. [CrossRef]

55. Bushell, G.; Yan, Y.; Woodfield, D.; Raper, J.; Amal, R. On techniques for the measurement of the mass fractal dimension of aggregates. Adv. Colloid Interface Sci. 2002, 95, 1-50. [CrossRef]

56. Brasil, A.M.; Farias, T.L.; Carvalho, M.G. A recipe for image characterization of fractal-like aggregates. J. Aerosol Sci. 1999, 30, 1379-1389. [CrossRef]

57. De Temmerman, P.-J.; Van Doren, E.; Verleysen, E.; Van der Stede, Y.; Francisco, M.A.D.; Mast, J. Quantitative characterization of agglomerates and aggregates of pyrogenic and pprecipitated amorphous silica nanomaterials by transmission electron microscopy. J. Nanobiotechnol. 2012, 10, 24. [CrossRef]

58. Boldridge, D. Morphological Characterization of Fumed Silica Aggregates. Aerosol Sci. Technol. 2010, 44, 182-186. [CrossRef]

59. Nel, A.; Mädler, L.; Velegol, D.; Xia, T.; Hoek, E.M.V.; Somasundaran, P.; Klaessig, F.; Castranova, V.; Thompson, M. Understanding biophysicochemical interactions at the nano-bio interface. Nat. Mater. 2009, 8, 543-557. [CrossRef]

60. Chu, Z.; Huang, Y.; Tao, Q.; Li, Q. Cellular uptake, evolution, and excretion of silica nanoparticles in human cells. Nanoscale 2011, 3, 3291-3299. [CrossRef]

61. Jiang, J.; Oberdörster, G.; Biswas, P. Characterization of size, surface charge, and agglomeration state of nanoparticle dispersions for toxicological studies. J. Nanopart. Res. 2009, 11, 77-89. [CrossRef]

62. Powers, K.W.; Brown, S.C.; Krishna, V.B.; Wasdo, S.C.; Moudgil, B.M.; Roberts, S.M. Research Strategies for Safety Evaluation of Nanomaterials. Part VI. Characterization of Nanoscale Particles for Toxicological Evaluation. Toxicol. Sci. 2006, 90, 296-303. [CrossRef]

63. Roebben, G.; Rasmussen, K.; Kestens, V.; Linsinger, T.P.J.; Rauscher, H.; Emons, H.; Stamm, H. Reference materials and representative test materials: The nanotechnology case. J. Nanoparticle Res. 2013, 15, 1455-1468. [CrossRef]

64. Xia, T.; Kovochich, M.; Brant, J.; Hotze, M.; Sempf, J.; Oberley, T.; Sioutas, C.; Yeh, J.I.; Wiesner, M.R.; $\mathrm{Nel}$, A. Comparison of the Abilities of Ambient and Manufactured Nanoparticles To Induce Cellular Toxicity According to an Oxidative Stress Paradigm. Nano Lett. 2006, 6, 1794-1807. [CrossRef] [PubMed]

65. Potapov, V.V.; Zhuravlev, L.T. Temperature Dependence of the Concentration of Silanol Groups in Silica Precipitated from a Hydrothermal Solution. Glas. Phys. Chem. 2005, 31, 661-670. [CrossRef]

66. Zhuravlev, L. The surface chemistry of amorphous silica. Zhuravlev model. Colloids Surf. A Phys. Eng. Asp. 2000, 173, 1-38. [CrossRef]

67. Potapov, V.V. Physical and chemical processes of nanosilica precipitation from hydrothermal solution. Theor. Found. Chem. Technol. 2003, 37, 1-9.

68. Potapov, V.V. Method of Utilization of Geothermal Silica for Liquid Glass Production. Patent of Russian Federation on Invention No. 2186025, 25 December 2000.

69. Potapov, V.V. Method of Precipitaion of Nanosilica from Hydrothermal Heat Carrier with Production of Metal's Silicates. Patent of Russian Federation on Invention No. 2259318, 8 August 2003.

70. Sobolev, K.; Gutiérrez, M.F.; Society, T.A.C. How Nanotechnology Can Change the Concrete World. Prog. Nanotechnol. 2014, 10, 117-120.

71. Sanchez, F.; Sobolev, K. Nanotechnology in Concrete-A Review. Constr. Build. Mater. 2010, 24, $2060-2071$. [CrossRef]

72. Flores-Vivian, I.; Pradoto, R.G.K.; Moini, M.; Kozhukhova, M.; Potapov, V.; Sobolev, K. The effect of $\mathrm{SiO}_{2}$ nanoparticles derived from hydrothermal solutions on the performance of portland cement based materials. Front. Struct. Civ. Eng. 2017, 11, 436-445. [CrossRef] 
73. Fediuk, R. Composite Binders for Concretes with Improved Shock Resistance. Inorg. Mater. 2019, 10, 1177-1184. [CrossRef]

74. Svintsov, A.P.; Shchesnyak, E.L.; Galishnikova, V.V.; Fediuk, R.; Stashevskaya, N.A. Effect of nano-modified additives on properties of concrete mixtures during winter season. Constr. Build. Mater. 2020, 237, 117527. [CrossRef]

75. Artamonova, O.; Slavcheva, G.; Chernyshov, E.M. Effectiveness of combined nanoadditives for cement systems. Inorg. Mater. 2017, 53, 1080-1085. [CrossRef]

76. Elistratkin, M.Y.; Minakov, S.V.; Shatalova, S.V. Composite binding mineral additive influence on the plasticizer efficiency. Constr. Mater. Prod. 2019, 2, 10-16.

77. Potapov, V.; Efimenko, Y.; Gorev, D. Modification of concrete by hydrothermal nanosilica. Nanotechnologies Constr. A. 2019, 11, 248-265.

78. Potapov, V.; Efimenko, Y.; Gorev, D. Determination of the amount of $\mathrm{Ca}(\mathrm{OH})_{2}$ bound by additive nano-SiO in cement matrices. Nanotechnol. Constr. A 2019, 11, 415-432. [CrossRef]

79. Potapov, V.V.; Kashutin, A.N. Method of Increasing of Concrete's Compressive Strength by Using of Nanosilica Recovered from Hydrothermal Solution. Patent of Russian Federation on Invention No. 259739, 5 August 2015.

80. Potapov, V.V.; Revina, A.A.; Baranova, E.K. The optical properties of nanodisperse silica in hydrothermal solutions. Russ. J. Phys. Chem. A 2008, 82, 1002-1009. [CrossRef]

81. Revina, A.A.; Potapov, V.V.; Baranova, E.K.; Smirnov, Y.V. Research of interaction of nanosilica and metall's nanoparticles by the method of spectrophotometry. Phys. Chem. A 2013, 87, 262-269.

82. Zelenkov, V.N.; Potapov, V.V. Hydrothermal nanosilica in agricultural and crop bitechnology. Nanoindustry 2020, 1, 22-33.

83. Zelenkov, V.N.; Petrichenko, V.N.; Potapov, V.V.; Eliseeva, L.G.; Ivanova, M.I.; Latushkin, V.V.; Novikov, V.B. Verification of the complex preparation of hydrothermal nanosilica with krezacin for hydroponic growing of lettuce in a closed system of the ITS-1 phytotron. Curr. Biotechnol. 2018, 3, 378.

84. Zelenkov, V.N.; Petrichenko, V.N.; Potapov, V.V. Method of Hydrothermal Nanosilica Using for Production of Lettuce in Agricultural Techonological Systems. Patent of Russian Federation on Invention No. 2701495, 11 December 2018.

85. Zelenkov, V.N.; Ivanova, M.I.; Potapov, V.V. Hydrothermal Nanosilica in the Agrotechnology of Radish Cultivated in the Conditions of Low Positive Temperature. In Proceedings of the AIP Conference, Yekaterinburg, Russia, 15-17 November 2018.

86. Lapin, A.A.; Kalayda, M.L.; Potapov, V.V.; Zelenkov, V.N.; Voropaeva, N.L. The influence of hydrothermal nanosilica powder aquaspersions on the vital capacity of Daphnia Magna Straus Crustataceans. Int. J. Nanotechnol. 2018, 15, 422-432.

87. Zelenkov, V.N.; Potapov, V.V. Method of Inhibition of Mealy Dew of Tomatoes. Patent of Russian Federation on Invention No. 2646058, 6 July 2017.

88. Potapov, V.V.; Sivashenko, V.N.A.; Zelenkov, V.N. Nanodispersed silicon dioxide: Plant growing and veterinary science. Nanoindustry 2013, 4, 18-25.

89. Potapov, V.V. Method of Hydrothermal Nanosilica Using as Food Additive. Patent RU on Invention No. 2638322, 12 December 2016.

90. Potapov, V.V. Method of Amorphous Hydrothermal Nanosilica Using in Poultry-Keeping. Patent RU on Invention No. 2655739, 5 June 2017.

91. Potapov, V.V.; Muradov, S.V.; Sivashenko, V.A.; Rogatyh, S.V. Nanodispersed silicon dioxide: Applications in medicine and veterinary. Nanoindustry 2012, 3, 32-36.

(C) 2020 by the authors. Licensee MDPI, Basel, Switzerland. This article is an open access article distributed under the terms and conditions of the Creative Commons Attribution (CC BY) license (http://creativecommons.org/licenses/by/4.0/). 